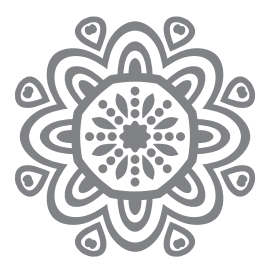

\title{
Tasawuf Qurani Jawi Ki Ageng Suryomentaram Studi Kawruh Jiwa
}

\author{
Abd. Muid N.' ${ }^{1}$ Mulawarman Hannase ${ }^{2}$, dan Abdullah Safei ${ }^{3}$ \\ ${ }^{1)}$ Dosen UIN Syarif Hidayatullah Jakarta DPK Institut PTIQ Jakarta \\ ${ }^{2)}$ Dosen Program Pascasarjana Institut PTIQ Jakarta \\ ${ }^{3)}$ Magister Ilmu Al-Quran dan Tafsir Institut PTIQ Jakarta \\ Email: ${ }^{1)}$ balesaloe@gmail.com, ${ }^{2}$ mhannase@yahoo.com, ${ }^{3)}$ abdullahsafei27@gmail.com \\ Hp. ${ }^{3)} 08170958106 / 089507642362$
}

\begin{abstract}
Kawruh jiwa Ki Ageng Suryomentaram focuses on human feeling in spiritual matters to live a happy life and not just physical aspects. The spiritual aspect must grow on the sense of self itself, while the physical aspects will arise after the growth of the spiritual aspects that are carried out. The spiritual aspect must be in line and side by side with the physical aspect to produce a complete sense of human self. Ki Ageng Suryomentaram asserted that he invited us as Indonesian people to feel the feelings of life, examine every taste, and achieve the true meaning of happiness. Happiness is not out there, but inside yourself. Happiness is free, does not depend on time, place and circumstances. This study tries to invite all of us to be able to feel the happiness that is in us so that it reaches a complete human being with essential happiness given by the Creator, Allah SWT.
\end{abstract}

Keywords: kawruh joul, self, spiritual 


\section{A. Pendahuluan}

Ki Ageng Suryomentaram adalah salah satu pangeran dari Sri Sultan Hamengku Buwono ke VII tepatnya putera ke lima puluh lima dari tujuh puluh delapan bersaudara. Ia meninggalkan gelar kepangeranannya sebab merasa tidak pernah menemukan "orang". "Seprana-seprana aku durung kepethuk wong", begitulah kira-kira kalimat yang terlontar olehnya karena relasi yang terbentuk di keraton adalah relasi abdi-dalem, menyembah dan disembah, memerintah dan diperintah, mencari kesenangan dan menghindarkan dari penderitaan. Hal yang dikejar hanyalah kesenangan pada fisik bukan pada spiritual. Semua orang mengejar semat, drajat, kramat, dan mengira itulah faktor utama untuk bahagia. Setiap hari-harinyadilakukanuntuk berlomba-lomba menjadi hedon. Padahal tidak ada moralitas berdasar sesuatu yang ideal, tapi yang nyata ada rasa sakit menuju senang, dan menghindari diri dari rasa sakit. ${ }^{1}$

Rasa senang disebabkan oleh keinginan yang tercapai, dan keinginan yang tercapai itu selalu mulur sehingga muncul keinginan baru yang belum tercapai, maka timbullah rasa susah. Kesusahan itu disebabkan karena keinginan tidak tercapai, padahal keinginan yang tidak tercapai itu mesti mungkret sehingga apa yang diinginkan menjadi mungkin tercapai, maka akan tercapailah keinginan yang telah mungkret itu dan rasa senangpun kembali timbul karenanya. ${ }^{2}$

Kegelisahan Ki Ageng Suryomentaram adalah tentang apakah kebahagiaan itu sesungguhnya. Menurut Ki Ageng, di atas bumi, di bawah kolong langit ini tidak ada barang yang pantas di cari, dihindari atau ditolak secara mati-matian. Meskipun demikian manusia tentu berusaha mati-matian untuk mencari, menghindari atau menolak sesuatu, walaupun itu tidak sepantasnya dicari, ditolak atau dihindarinya. ${ }^{3}$ Hatinya berkata, "sebaiknya kucari uang sebanyakbanyaknya agar menjadi kaya raya seperti orang itu, dan jangan sampai miskin seperti orang ini, agar bisa mengejek orang ini dan jangan sampai diejek orang itu. Dan aku harus memperoleh derajat yang luhur, supaya mulia seperti orang itu, dan jangan sampai hina seperti orang ini, sehingga terhormat seperti orang itu dan tidak diremehkan seperti orang ini. Harus kucari kramat (kekuasaan) yang besar, supaya berkuasa dan dapat menaklukan orang itu. Jangan sampai lemah

\footnotetext{
${ }^{1}$ Ryan Sugiarto,dkk, Ilmu Kawruh Jiwa Suryomentaram, Riwayat, dan Jalan Menuju Bahagia, Yogyakarta: Dinas Kebudayaan Istimewa Yogyakarta, 2015, hlm. ix-x.

${ }^{2}$ Abdurrahman El-Ashiy, Makrifat Jawa untuk Semua, Jakarta: Serambi Ilmu Semesta, 2011, Cet. I, hlm. 187.

${ }^{3}$ Ratih Sarwiyono, Ki Ageng Suryomentaram Sang Plato Dari Jawa, Yogyakarta: Cemerlang Publishing, 2017, hlm. 57.
} 
dan ditaklukan orang ini”. Begitu hebat usahanya hingga ia merasa, lebih baik mati jika tidak tercapai!4

\section{B. Biografi Ki Ageng Suryomentaram}

Kraton Kesultanan Yogyakarta merupakan salah satu kerajaan Islam di Pulau Jawa. Awalnya, Ki Ageng Panembahan karena keberhasilannya membantu sultan Pajang, maka mendapat hadiah tanah di Mataram yang kemudian berkembang menjadi kerajaan Mataram Islam yang besar. Kerajaan Islam Mataram ini mengalami kejayaan pada masa pemerintahan Raden Mas Rangsang yang lebih dekat dikenal dengan Sultan Agung Hanyakrakusuma. (1613-1645). Sultan Agung sangat anti kepada Belanda, terbukti pada tahun 1628 dan 1629 ia mengirimkan pasukannya ke Batavia untuk menggempur Belanda. ${ }^{5}$

Yogyakarta merupakan kota kerajaan terakhir yang menjadi salah satu pusat budaya di pulau Jawa. Saat ini, Yogyakarta menjadi ibukota dari salah satu provinsi di Indonesia yang berstatus daerah istimewa dan memiliki Keraton Yogyakarta sebagai peninggalan bersejarah. Keraton Yogyakarta berdiri setelah perjanjian Giyanti atau Palihan Nagari pada tanggal 29 Rabiulakir 1680 (Jw) atau 13 Februari 1755 antara Sri Sunan Paku Buwana III dengan Pangeran Mangkubumi. Keraton Yogyakarta merupakan perwujudan cipta karya estetik Pangeran Mangkubumi, yang setelah menjadi raja bergelar Sultan Hamengku Buwana I Senapati Ing Ngalaga Abdurrahman Sayidin Panatagama Kalifatullah. Pangeran Mangkubumi dikenal sebagai ahli bangunan yang unggul sejak masih muda. Ia memimpin pembangunan Keraton Yogyakarta, menentukan bentuk dan ukurannya, serta menyelesaikannya kurang lebih satu tahun. ${ }^{6}$

Gusti Raden Mas Murtejo adalah nama asli Sri Sultan Hamengku Buwono VII anak dari seorang Sri Sultan Hamengku Buwono VI yang lahir pada 4 Februari 1839. Sri Sultan Hamengku BuwonoVII naik tahta menggantikan ayahnya sejak 1877. Ia menjadi seorang raja di Kraton Ngeyogyakarta Hadiningrat sejak 1877-1921. Ketika beliau memimpin banyak hal yang dilakukannya. Ketika itu masa krisis yang begitu hebat menimpah Yogyakarta karena gempa bumi yang meluluhlantahkan Yogyakarta. Disanalah peranan seorang raja yang bernama Sri Sultan Hamengku BuwonoVII alias Gusti Raden Mas Murtejo melakukan pembangunan fisik dengan menata ulang Yogyakarta. Selain itu juga, pembangunan ekonomi secara besar-besaran juga dilakukannya antara lain

\footnotetext{
${ }^{4}$ Abdurrahman El-Ashiy, Makrifat Jawa Untuk Semua, hlm. 190.

${ }^{5}$ Sekretariat Negara, Seri Profil Propinsi Republik Indonesia, hlm. 41. Dinukil dari Sa'adi, Nilainilai Mental Islam Dalam Kebatinan Kawruh Jiwa Suryomentaram, hlm. 157.

${ }^{6}$ R.M. Soemardjo Nitinegoro, Sejarah Berdirinya Kota Kebudayaaan Ngayogyakarta Hadiningrat, Yogyakarta: Foundation of Higher Education PUTRAJAYA, 1980, hlm. 30 dan 68.
} 
pembangunan pabrik vanili di Kulon Progo, beberapa pabrik gula, dan banyak fasilitas baru yang di bangun oleh Sri Sultan Hamengku Buwono VII. Pada masa pemerintahannya ada 17 belas pabrik gula yang didirikannya dan setiap pabrik memberikan peluang kepadanya untuk menerima dana sebesar Rp. 200.000,-. Hal itu menjadikan Sri Sultan Hamengku BuwonoVII sangat kaya sehingga dijuluki Sultan Suguh. Masa pemerintahan Sri Sultan Hamengku BuwonoVII juga masa transisi menuju modernisasi, dikarenakan banyak sekolah modern didirikan dan bahkan ia mengirim putera-puteranya belajar hingga ke negeri Belanda.

Setelah tidak lagi menjabat sebagai raja, Sri Sultan Hamengku BuwonoVII pernah mengatakan bahwa tidak pernah ada seorang Raja yang meninggal di Kraton setelah saya, karena sesuai dengan ucapanya tersebut ada dua raja setelah dirinya yang meninggal dunia di luar Kraton, yaitu Sri Sultan Hamengku BuwonoVIII meninggal dunia ditengah perjalanan ke luar kota dan Sri Sultan Hamengku Buwono IX meninggal di Amerika Serikat. Bagi masyarakat Jawa, sebuah kebanggaan jika seseorang meninggal di rumahnya sendiri. Sri Sultan Hamengku BuwonoVII meninggal di Pesanggrahan Ngambarrukma pada tanggal 30 Desember 1931 dan di makamkan di Imogiri.

Ngarsadalem Sampeyan dalem Hingkang Sinuhun Kanjeng Sultan Hamengku BuwonoVII, memiliki tiga Garwadalem Padmi (Permaisuri). Pertama, Gusti Kanjeng Ratu Kencono, yang kemudian dikakebonaken (diceraikan) dengan nama Gusti Kanjeng Ratu Wandhan. Beliau adalah anak dari Raden Ali Basah Abdulmustapa Senthot Prawiradirjo. Garwadalem Padmi Kedua, Gusti Kanjeng Ratu Hemas, anak dari kanjeng Radeng Tumenggung Joyodipuro. Sedang yang ketiga, Gusti Kanjeng Ratu Kencono, anak dari Bendara Pangeran Harya Hadinegoro anak dari putera dalem Hingkang Sunuhun Kanjeng Sultan Hamengku Buwono II.

Selain tiga permaisuri tersebut, Sri Sultan Hamengku BuwonoVII juga mempunyai 18 Garwa ampeyan. Dari semua isterinya Sri Sultan Hamengku BuwonoVII memiliki anak sebanyak 78 orang.'

Ki Ageng Suryomentaram adalah anak ke dua dari Sri Sultan Hamengku Buwono VII dari Garwa Ampeyan B.R.A. Retnomandoyo. Ki Ageng Suryomentaram memiliki 6 saudara, yakni satu kakak perempuan, Bendara Raden Ayu (B.R.A.) Mangunnegoro. Adiknya berurutan ; Bendara Pangeran Harya (B.P.H.) Joyokusumo, B.P.H. Hadiwinoto, Bendara Raden Mas (B.R.M.) Subono, dan B.R.M. Sumaul Ngirki. ${ }^{8}$

${ }^{7}$ Ryan Sugiarto, dkk, Suryomentaram, Riwayat, dan Jalan Menuju Bahagia, Yogyakarta: Dinas Kebudayaan Daerah Istimewa Yogyakarta, 2015, hlm. 2-4

${ }^{8}$ Ryan Sugiarto, dkk, Suryomentaram, Riwayat, dan Jalan Menuju Bahagia, hlm. 5. 
Sebagai seorang putera raja Sultan Hamungku Buwono VII, Bendara Raden Mas (BRM) Kudiarmaji yaitu bernama Suryomentaram kecil hidup dan dibesarkannya dalam suasana kehidupan tradisi kraton yang bersifat feudalis, suatu tata cara hidup kolektif yang menghargai orang berdasarkan keturunan darah raja dan bukan karena prestasinya bersifat mistis, magis dan okultis serta penuh dengan etika khas kraton, sehingga orang tidak dapat hidup secara bebas mengekspresikan ide, pendapat, sikap dan pandangan karena adanya batasan berbagai nilai etika tersebut. ${ }^{9}$

Sebagaimana anak kecil, Bendara Raden Mas (BRM) Kudiarmaji nama dari Suryomentaram kecil, Ia bermain-main, belajar menari, dan belajar wayang. Di masa remaja Raden Mas Kudiarmaji sangat pandai menari dan menjadi penari di Kraton. Hingga memerankan puteri Mediun atau Retnodumilah karena ke luwesannya dalam menari melebihi kelenturan gerak tari seorang wanita. Sebab di usia remaja Raden Mas Kudiarmaji kelihatan cantik seperti wanita.

Dari segi perawakan, R.M. Kudiarmaji mempunyai rambut panjang, wajah lonjong, bermata lebar, hidung mancung, dan mempunyai daun telinga besar. Dan ia memelihara kumis tebal di usia dewasa. Suryomentaram lebih dekat dengan dua orang dari 78 saudaraya yang lain. Pertama ia dekat dengan G.P.H Notoprojo, anak ke-31 dari Sri Sultan Hamengku Buwono VII dari Garwa Padmi Gusti Kanjeng Ratu Kencono. Dan ia selalu berdiskusi tentang kebatinan. Kedua ia dekat dengan B.P.H. Suryadiningrat, anak ke-42 dari Sri Sultan Hamengku Buwono VII, dari Garwa Ampeyan Bendara Raden Ayu (B.R.A.) Retnojuwito. Dan ia selalu berdiskusi dan belajar tentang ilmu politik dengan B.P.H. Suryadiningrat.

Sedang dengan saudara-saudararanya yang lain, B.R.M. Kudiarmaji menempuh pendidikan dasar di Sekolah Kraton Srimanganti, setara dengan sekolah dasar yang berada di sekitar lingkungan Kraton. Setelah menyelesaikan sekolah dasarnya, ia mengikuti kursus Klein Ambtenaar (Pegawai Sipil Junior). Setelah selesai Klein Ambtenaar ia menjadi tenaga administratif di Residen Yogyakarta selama dua tahun. Kemudian selain kursus Klein Ambtenaar, ia juga mempelajari Bahasa Belanda, Bahasa Arab, dan Bahasa Inggris. ${ }^{10}$ Dan ia juga memiliki minat yang begitu kuat dalam belajar filsafat, terutama filsafat hidup. Ia juga rajin mengerjakan shalat dan setiap ada guru atau kiai yang terkenal di datangi untuk belajar ilmunya, salah satu guru atau kiai yang di datanginnya adalah $\mathrm{KH}$ Ahmad Dahlan (Tokoh Pendiri Muhammadiyah). ${ }^{11}$

\footnotetext{
${ }^{9}$ Sa'adi, Nilai Kesehatan Mental Islam Dalam Kebatinan Kawruh Jiwa Suryomentaram, Jakarta: Puslitbang Lektur Keagamaan Badan Litbang dan Diklat Kementerian Agama RI, 2010, Cet. I, hlm. 222.

${ }^{10}$ Ryan Sugiarto, dkk, Suryomentaram, Riwayat, dan Jalan Menuju Bahagia, hlm. 6-7.

${ }^{11}$ Sa'adi, Nilai Kesehatan Mental Islam Dalam Kebatinan Kawruh Jiwa Suryomentaram, hlm. 159.
} 
Pada saat usia B.R.M. Kudiarmaji 18 tahun, B.R.M. Kudiarmaji diangkat menjadi seorang pangeran dengan gelar Bendoro Pangeran Haryo Suryomentaram atau RM Suryomentaram. ${ }^{12}$ Tapi penganugrahan gelar sebagai pangeran itu justru menggelisahkannya. Pangeran Suryomentaram mulai merasakan ada sesuatu yang kurang dalam hatinya. Ia merasa setiap saat hanya bertemu dengan yang disembah, yang diperintah, yang dimarahi, dan yang dimintai. Dia tidak puas dengan semua itu karena merasa tidak pernah bertemu dengan "orang"(manusia sejati). Di lingkungan keraton dia hanya menemukan sembah, perintah, marah, minta, dan tidak pernah bertemu dengan "orang". Iapun masygul dan kecewa, justru tatkala ia mendapati dirinya sebagai seorang pangeran yang kaya dan berkuasa. ${ }^{13}$

Kegelisahannya tentang kebahagiaan dimulai ketika pada suatu hari Pangeran Suryomentaram merasa terperangah ketika menyaksikan petanipetani yang bekerja di sawah. Dari jendela kereta api yang mengantarnya ke pesta perkawinan di Keraton Surakarta, ia manilai bahwa jenis pekerjaan itu menyebabkan sakit punggung. Ia menilai di saat orang mengalami penderitaan yang berat, mbungkak mbungkuk tandur, orang-orang dilingkungannya malah menikmati kehidupan yang mewah tanpa perlu bersusah payah mendapatkannya, karena telah memiliki keistimewaan sejak lahir. Namun demikian, sebagimana diungkapkan oleh Prawirawiwara, teman dekat sang pangeran, apakah para petani tidak lebih bahagia tinimbang sang pangeran, yang hanya bisa meratapi dirinya sendiri mengasihi mereka, karena setidaknya para petani tersebut sudah puas dengan hasil sawah yang dimilikinya.

Di sisi lain Suryomentaram mengalami kejumudan terhadap kehidupan keraton yang dialaminya. Aktivitas keraton yang ditemuinya hingga memasuki masa remaja adalah interaksi ndoro abdi, yang nampak darinya hanyalah " Yang disembah", yang dihiba-hiba", "Yang diperintah", sehingga yang berlaku didalamnya adalah memerintah, marah, dan memohon. Di lingkungannya sang pangeran hanya mengetahui tuan-tuannya dan kekecewaan-kekecewaan yang mereka alami. ${ }^{14}$

Secara ekonomi, karena di bawah pemerintahan kolonial Belanda, praktis rakyat sangat tidak mandiri, menderita, miskin, dan keterbelakangan secara merata termasuk masyarakat Jawa yang menjadi lingkungan Suryomentaram. Raja-raja Nusantara tidak dapat berbuat banyak untuk rakyat karena secara politis juga di bawah kendali pemerintahan kolonial Belanda. Akibatnya bangsa Indonesia juga mengalami kemudengan secara budaya.

${ }^{12}$ Ryan Sugiarto, Psikologi Raos Saintifikasi Kawruh Jiwa Ki Ageng Suryomentaram, Yogyakarta: Pustaka Ifada, 2015, Cet. I, hlm. 26.

${ }^{13}$ Abdurrahman El-Ashiy, Makrifat Jawa untuk Semua, hlm. 24.

${ }^{14}$ Ryan Sugiarto, Psikologi Raos Saintifikasi Kawruh Jiwa Ki Ageng Suryomentaram, hlm. 26. 
Ini terbukti bahwa pada masa itu tidak muncul sastrawan, pujangga dan filosof dengan karya besar yang layak dibanggakan yang mampu mencerahkan dan memajukan bangsa. Bahkan rakyat cenderung menyukai paham yang mistis, ramalan-ramalan, dan gugon tuhon yang tidak realistis dan irrasional. Apalagi dari segi pendidikan sangat memprihatinkan, hanya $2 \%$ rakyat yang dapat menikmati sekolah (pendidikan dasar), itupun dari kalangan sangat terbatas, sehingga praktistidak ada prestasi di bidang sains dan teknologi bagi bangsa Indonesia. ${ }^{15}$

\section{Masa Pencarian Makna Hidup, Ide, dan Pemikiran Awal}

Manusia mengacu kepada esensi (mahiyyah) manusia itu sendiri. Ini terlontar ketika kita berbicara siapa itu manusia?. Maka ketika kita ingin mengetahui siapa itu manusia, kita harus terlebih dahulu mengetahui esensi (mahiyyah) sesuatu. Menurut para filsuf atau ahli logika, esensi (mahiyyah) harus kita ketahui dengan mengenal jenis (jins), spesies (nau) dan differentia atau ciri khas (fashl) dari sesuatu itu. Manusia adalah "jenis" makhluk hidup dan makhluk hidup itu sendiri terbagi atas tiga spesies: tumbuhan, hewan dan malaikat. Adapun "spesies" manusia adalah "hewan" yang didefinisikan sebagai "mahkluk hidup yang bisa mengindra dan bergerak." Dan "ciri khas" yang membedakan manusia dengan hewan lain adalah berbicara (nâthiq). Kemampuan berbicara (nâthiq) melibatkan kemampuan untuk memahami simbol, baik berupa huruf atau kata (suara yang bermakna), dan menyampaikan kepada orang lain sehingga istilah ini disebut dengan memahami "bahasa". Adapun manusia disebut mampu memahami bahasa karena manusia memiliki akal (intelek) yang diberikan Allah SWT kepadanya. Dengan demikian ciri khas inilah yang menjadi sebab manusia berbeda dengan hewan lain. Itulah sebabnya kemudian manusia disebut dengan makhluk rasional (a rational being), sebagai terjemahan dari ( al-hayawân alnâthiq) serta jiwa yang diberikan kepada manusia disebut dengan jiwa rasional (al-nafs al-nuthiqiyyah) atau cukup disebut akal saja. Sebagai makhluk berakal, manusia sering ditempatkan antara hewan dengan nafsunya, dan malaikat dengan akalnya, hingga jadilah manusia makhluk yang unik yang mempunyai nafsu dan akal. ${ }^{16}$

${ }^{15}$ Sekretariat Negara, Seri Profil Propinsi Republik Indonesia, Jakarta: Depdikbud, 1993, hlm. 52. Dinukil dari Sa'adi, Nilai-nilai Mental Islam Dalam Kebatinan Kawruh Jiwa Suryomentaram, hlm. 160 .

${ }^{16}$ Mulyadi Kartanegara, Lentera Kehidupan Panduan Memahami Tuhan, Alam, dan Manusia, Bandung: Mizan, 2017, Cet. I, hlm.135-136. 
Berangkat dari hal tersebutlah, Suryomentaram menilai esensi kawruh jiwa adalah deskripsi tentatif hakekat dan dinamika rasa setiap manusia. Ia merupakan hasil perenungan fenomenologis, pemikiran spekulatif yang terus menerus, observasi dan refleksi intuitif yang jernih, mendalam serta pengalaman hidup pribadi Suryomentaram serta lingkungan sosial yang di amati, dalam upaya mengenal jiwa manusia secara "otentik" dan komprehensif. Oleh karena itu ia menjelaskan betapa penting dan rumitnya mempelajari jiwa manusia. Diantaranya adalah:

Pertama, Djiwa punika mboten kawon penting tinimbang raga, sarehne kawontenanipun mboten kasatmata pramila langkung angle dipun sumerep. Jiwa itu tidak kalah penting dari pada raga. Karena keadaannya yang tidak tampak oleh mata, maka ia sulit untuk diamati. Esensi jiwa menurut Suryomentaram adalah raos (rasa) atau kraos (merasakan) dan pangertos (pengertian, insight). ${ }^{17}$

Kedua, Pirantosing manungsa punika raga (ingkang kanthi pantja indera) lan djiwa. Djiwa punika wudjudipun raos (kraos) gesang lan pangertos. Kraso gesang punika kadosta kraos aku, kraos ana, kraos bungah, kraos susah, karep lan sapanunggalanipun. Pangertospunika putusan kangge netepaken prakawis ingkang saking pabtja indera lan kraosipun. Piranti manusia itu raga dengan panca inderanya dan jiwa. Dan jiwa itu wujudnya rasa hidup dan pengertian (kognisi, intuisi). Rasa hidup itu seperti rasa aku, rasa ada, rasa senang, rasa susah, keinginan dan sebagainya. Dengan metode filsafat, Suryomentaram mengidentifikasi esensi (hakekat) manusia dari dua sifat dasar alam benda di dunia. Secara ringkas dan garis besar tentang jenis dan tingkatan benda-benda tersebut dengan spesifikasinya:

a. Jinising alam barang pejah kadosta siti, toya, latu, angin, gas lan sanessanesipun (jenis alam benda mati seperti tanah, air, api, udara, gas dan sebagainya).

b. Jinising alam gesang kadosta taneman, kewan lan manungsa (jenis alam benda hidup seperti tumbuhan, binatang dan manusia).

c. piranti raos utawi kraos gesang lan pangertos (rasa atau kesadaran hidup dan pengertian, akal) yang merupakan identitas esensial manusia. Manusia memiliki raos gesang (rasa hidup) yang meliputi raos bungah, raos susah, raos aku lan raos karep (kepinginan) nglestantunaken gesang lan pangertosan kanthi penggalih lan cipta ${ }^{18}$ ( rasa keinginan untuk melestarikan hidup serta pengertian dengan

${ }^{17}$ Suryomentaram, Ilmu Djiwa, t.k, t.p, t.t, hlm. 1. Dinukil dari buku Sa'adi, Nilai Kesehatan Mental Islam Dalam Kebatinan Kawruh Jiwa Suryomentaram, hlm. 164.

${ }^{18}$ Grangsang Suryomentaram, Kawruh Begja Wejanganipun Ki Ageng Suryomentaram, hlm. 80. 
berpikir dan mencipta) inilah yang membedakan dengan benda mati, tumbuhan, dan binatang. Dengan identitas esensial tersebut manusia dapat berkembang dan mengembangkan potensi-potensi kemanusiannya.

Ketiga, Wategipun barang pejah punika mboten obah kajawi dipun obahaken, mboten tuwuh, mboten rembaka, mboten gadhah raos penggalih lan cipta. ${ }^{19}$ Sifat alam benda mati adalah tidak bergerak kecuali digerakkan, tidak tumbuh, tidak berkembang biak, tidak berperasaan dan tidak berpikiran.

Keempat, Watakipun barang gesang kados taneman inggih punika gadhan watak obah piyambak ananging mboten saged owah saking panggenanipun piyambak, saged thukul, tuwuh lan rembaka piyambak utawi dipun biyantu, tanpa raos lan penggalih. ${ }^{20}$ Sifat benda hidup seperti tanaman adalah dapat bergerak sendiri tetapi tidak dapat pindah tempat sendiri, bisa tumbuh dan berkembang biak baik dengan dirinya sendiri atau dengan dibantu, tidak berperasaan dan pikiran.

Kelima, Kewan gadhah watak saged obah piyambak kados mlampah piyambak, liar, tuwuh saged ageng lan rembaka lan pejah, gadhah raos luwe, ngelak, pengin benten jinis, nanging mboten gadhah raos sedih lan penggalih". ${ }^{21}$ Hewan bisa bergerak sendiri seperti berjalan, lahir, tumbuh besar, berkembang biak, kemudian mati, punya rasa instink lapar, haus, ingin dengan lain jenis, tetapi tidak punya perasaan dan pikiran.

Keenam, Watakipun manungsa punika saged obah, pindah panggenan piyambak, lahir, tuwuh ageng, dewasa, gadhah anak-anak, pejah lan gadhah raos gesang lan karep nglestantunaken kangge saening gesang kanthi penggalih lan cipta". ${ }^{22}$ Sifat manusia adalah dapat bergerak, dapat berpindah tempat sendiri, lahir, tumbuh, besar, dewasa, berketurunan, mati, mempunyai rasa (kesadaran) hidup dan keinginan untuk melestarikan kualitas hidup dengan perasaan dan pikiran.

Dengan esensi dasar manusia itulah, Suryomentaram mengembangkan pandangannya tentang eksistensi jiwa manusia dalam hidupnya, bukan dari perspektif teologi, tetapi dalam konteks peran sosial budayanya. Untuk itu maka

${ }^{19}$ Grangsang Suryomentaram, Kawruh Begja Wejanganipun Ki Ageng Suryomentaram, Buku I, Jakarta : CV. Haji Masagung, 1989, hlm. 34-35.

78.

${ }^{20}$ Grangsang Suryomentaram, Kawruh Begja Wejanganipun Ki Ageng Suryomentaram, hlm.

${ }^{21}$ Grangsang Suryomentaram, Kawruh Begja Wejanganipun Ki Ageng Suryomentaram, hlm. 78. 79.

${ }^{22}$ Grangsang Suryomentaram, Kawruh Begja Wejanganipun Ki Ageng Suryomentaram, hlm. 
eksistensi jiwa manusia akan berkembang optimal yang diidentifikasi sebagai berikut:

a. Gadhah Pangertos Lan Cipta

(sebagai Makhluk yang Berpikir dan Mencipta)

Dari sifat dasar manusia ini maka eksistensi manusia dalam konteks peran sosio-kulturalnya ditentukan oleh Sepinten anggenipun nggulawentah daya ciptanipun kangge pikantuk lan nuwuhaken ing bab pemanggih kawruh lan pangertosan menapa kemawon, ingkang anjalari kemajenganipun gesang bangsa manungsa. ${ }^{23}$ Sejauh mana ia mampu mengembangkan kemampuan berpikirnya untuk memperoleh dan mengembangkan ilmu pengetahuan apa saja, untuk memacu kemajuan kehidupan umat manusia. Itulah sebabnya maka ia sangat haus ilmu dan tekun belajar filsafat, agama dan bahasa asing. Ini tampaknya berangkat dari kesadarannya bahwa bangsa Indonesia begitu lama hidup dalam penderitaan penjajahan, bodoh,, miskin dan terbelakang karena akal rasional ilmiah tidak dibudayakan sehingga ilmu pengetahuan tidak berkembang.

b. Gadhah raos sami guyub lan penggalihan luhur (sebagai makhluk yang mempunyai perasaan sosial dan bercita-cita mulia)

Dalam konsep Suryomentaram rasa mengandung makna yang spektrumnya cukup luar, tidak sekedar sebagaimana dalam konteks psikologi yakni perasaan, yang meliputi aspek fisik (indra), persepsi, emosi, konasi, kognisi (ingatan), kesadaran intuisi bahkan juga bakat-bakat bawaan. Tentang eksistensi ini maka oleh Suryomentaram ditegaskan bahwa dalam kontek sosio- kulturalnya yaitu Tiyang utawi bangsa punika saged moncer lan misuwur manawi tansah saged ngupakara kanthi leres lan trap raos-raos ingkang saking panca indria, penggalihan luhur, panggayuh mulya, raos eling lan sadaya pirantos batin kados bakat-bakat kanthi ngrembaka sae. ${ }^{24}$ Seseorang atau bangsa dapat maju dan terkenal sejauhmana ia membudidayakan semua kekuatan potensial berupa panca indra, idealisme, cita-cita, kesadaran, dan bakat-bakat agar dapat berkembang secara benar dan maksimal.

\footnotetext{
${ }^{23}$ Grangsang Suryomentaram, Kawruh Begja Wejanganipun Ki Ageng Suryomentaram, Jilid II, Jakarta : CV. Haji Masagung, 1990, hlm. 87. 87.

${ }^{24}$ Grangsang Suryomentaram, Kawruh Begja Wejanganipun Ki Ageng Suryomentaram, hlm.
} 
Untuk itu maka dalam mewujudkan, menjaga dan mempertinggi kualitas eksistensi kejiwaan sesuai dengan kemanusiannya, maka manusia beradab dan bersosial tinggi mengembangkan sistem kehidupan yang meliputi, ${ }^{25}$

1) Nyekapi kabetahan gesang kanthi tenaga, pirantos, gladi, sinau, makarya, sesarengan (mencukupi kebutuhan hidup dengan tenaga, alat, latihan, belajar, bekerja dan kerjasama karena manusia hanya bisa hidup interaksi dan komunikasi dengan sesama manusia).

Orang yang berbudaya memenuhi kebutuhan hidup tidak sekedar dengan tenaga kasar (okol,otot), tapi lebih dari itu ia menggunakan akal, dengan alat, berlatih, belajar dan kalau perlu membentuk organisasi yang rapi dan efektif.

2) Nyipta samukawis barang lan sarananing gesang (menciptakan barangbarang dan peralatan keperluan hidup).

Kemampuan ini dapat terlaksana hanya kalau akal daya cipta benar-benar dilatih dan dikembengkan dengan mempelajari ilmu dan teknologi. Bangsa yang kaya dan maju dengan teknologi tinggi mampu mencukupi kebutuhan secara lebih mudah dengan peralatan yang semakin canggih dan mencipta barang yang bermutu kemudian mengekspornya ke negara-negara yang tertinggal dengan harga tinggi.

3) Nyipta kagunan kangge kaendahaning gesang (menciptakan karya seni untuk keindahan hidup).

Ini karena seni sebagai simbul dan ekspresi kelembutan serta keindahan budi. Dengan seni hidup menjadi indah. Keunggulan seni merupakan ujud ketinggian budi dan oleh rasa penciptanya, demikian pula keindahan dan kelembutan budi rasa seseorang dapat terlihat pada seperti apa kualitas produk seni yang ia senangi. Seni yang halus, sopan, bermoral biasanya hanya dikomunikasi oleh orang berkarakter seperti itu juga.

4) Nuwuhaken wontenipun gegayuhan raos gesang kamanungsan ingkang luhur lan mulya (menanamkan dan menumbuhkan rasa cita-cita hidup untuk pengabdian kepada kemanusiaan yang luhur dan mulia).

Manfaat dari sikap tersebut adalah:

a) Nuwuhaken raos sami (tumbuhnya rasa kebersamaan pada sesama, equalitas); 88-89.

${ }^{25}$ Grangsang Suryomentaram, Kawruh Begja Wejanganipun Ki Ageng Suryomentaram, hlm. 
b) raos sami saged nuwuhaken raos lega (rasa senasib dapat menumbuhkan rasa bebas);

c) raos lega nebihaken raos pasulayan (rasa rela dan lega lega menjauhkan rasa permusuhan);

d) saged tumindak kanthi bener dateng sesami (bertindak benar kepada sesama);

e) nebihaken saking lepat amargi mboten mangertos (menjauhkan dari kesalahan karena tidak tahu);

f) tuwuh raossekeca, tentram lan dame (tumbuh rasa enak, tentram dan damai);

g) mboten nabrak roosing liyan (tidak berbenturan dengan perasaan orang lain); dan

h) gesang sesrawungan bebrayan saged dados tentram lan dame (hidup bermasyarakat jadi tentram dan damai).

Selanjutnya, Suryomentaram membagi jiwa manusia bertingkat-tingkat atau berlapis-lapis, yang ia sebut dengan istilah ukuran. Setiap ukuran (tingkat) mempunyai karakter dan fungsi sendiri-sendiri. Tingkat-tingkat tersebut dari yang paling rendah atau luar sampai yang paling tinggi atau dalam sekaligus mencerminkan kualitas kepribadian individu dan kesehatan mentalnya yang secara garis besar dideskripsikan sebagai berikut: ${ }^{26}$

a. Juru Cathet: jiwa ukuran I (dimensi fungsi dan kesadaran aspek personal yang bersifat fisik sensual)

Pada dimensi ini manusia mencatat (mempersepsi) segala hal yang berhubungan dengan dirinya. Hasilnya berupa catatan-catatan (pesepsi, prakonsepsi dan sentimen) pada dimensi II. Pada dimensi ini tingkat kualitas individu baru mencapai pemenuhan kebutuhan fisik biologis yang kasat mata.

b. Cathetan-cathetan: jiwa ukuran II (sejumlah catatan hasil persepsi manusia, dimensi fungsi emosi)

Pada dimensi ini tindakan manusia dapat muncul didasari catatancatatan(persepsi, prakonsepsi, interest, sentimen primordial) yang berakar pada pengalaman hidupnya sejak masa kecil, baik yang menyenangkan

${ }^{26}$ Diskripsi disarikan dan diterjemahkan dengan redaksi penulis dari Grangsang Suryomentaram, Kawruh Jiwa, Jilid II, hlm. 106-131 
(afek positif) atau menyedihkan (afek negatif) bersifat bawah sadar. Pada dataran ini kualitas kejiwaan dan mental individu sudah lebih tinggi dari sebelumnya yaitu memenuhi kebutuhan emosional (rasa) seperti afeksi dan sosial, tetapi masih dibatasi oleh sekat-sekat primordial yang sempit seperti terdeskripsi pada bagian di bawah ini.

Dimensi ini dalam kehidupan manusia meliputi aspek-aspek sebagai berikut:

1) Raja darbe (harta benda)

2) Kahormatan (drajat, prestise dan gengsi sosial)

3) Penguawasa (pangkat, jabatan dan otoritas)

4) Kulawarga (keluarga, kerabat dan keturunan)

5) Golongan (organisasi, partai, lembaga, instansi dan sebagainya)

6) Bangsa (asal usul bangsa, ras suku, warna kulit, negara dan bahasa)

7) Jinis (jenis kelamin, seks)

8) Kapinteran (kepandaian, keahlian, keterampilan, profesi dan pendidikan)

9) Kabatinan (kepercayaann, agama aliran, ideologi)

10) Kawruh (ilmu pengetahuan)

11) Raos gesang (sentimen-sentimen lain yang umum terjadi pada manusia seperti budaya dan masyarakat)

c. Kramadhangsa: jiwa ukuran III (dimensi III, "si tukang pikir" atau kesadaran personal fungsi kognitif rasional)

Pada tingkat ini manusia bertindak berdasarkan pertimbangan kesadaran rasionalnya da realistis, tidak sekedar karena dorongan emosi dan sentimen pribadi (primordialisme) saja. Dengan demikian tingkat kualitas mentalnya sudah bagus tetapi masih sering mengalami hambatan dalam sosialisasi diri karena semata rasionalitas obyektif yang dikedepankan dalam pergaulan dan kurang bisa momong rasa lain. Perbuatan baik yang ia lakukan masih sebatas kesadaran rasional yang belum ideal belum sepenuhnya terbatas dari ikatan-ikatan primordialnya yang bersifat diskriminatif.

d. Manungsa Tanpa Tenger: jiwa ukura IV (dimensi manusia tanpa pamrih atau ciri diskriminator yakni manusia yang dalam bertindak sudah terbebas dari embel-embel yang menyebabkan seseorang merasa berbeda dengan orang lain). Dimensi ini bersifat intuitif dan altruistik sebagaimana digambarkan: 
"Manungsa tanpa tenger punika yen lelawan kaliyan tiyang sanes dados dhame, jalaran kraos sami, ingkang beda naming buntut-buntutipun. Raos dhame punika ngicali tapak awon ingkang nabet ing manah, lan punika pinangka wategipun manungsa tanpa tenger ingkang dasos gambaranipun jiwa sehat. Dados hasilipun nyinau Kawruh Jiwa, murugaken Jiwa dados sehat". ${ }^{27}$

Artinya: manusia tanpa ciri (pamrih) itu bila bertemu dengan orang lain merasa damai karena merasa sama, yang beda hanya predikat-predikat sampiran saja. Rasa damai itu menghilangkan kesan-kesan (kenangan) negatif dalam hati, dan itu sebagai watak manusia tanpa pamrih yang menjadi gambaran jiwa yang sehat. Jadi hasil belajar Kawruh Jiwa menjadi jiwa sehat.

Pada dimensi perasaan lain, sehingga yang muncul adalah perilaku altruistik tanpa pamrih, tanpa pertimbangan yang bersifat emosional dan sentimen (egoisme golongan, keturunan dan sebagainya). Ia telah mampu memudahkan secara berimbang rasa da rasionya dalam sosialisasi diri. Pada posisi ini manusia, menurut Suryomentaram, berada pada puncak kesehatan mental 100\%. ${ }^{28}$

Antara kramadhangsa (jiwa ukuran III) dan manungsa tanpa tenger (jiwa ukuran IV) terdapat jalan simpang tiga, yakni konflik batin karena adanya tarikan emosi (cathetan) berupa tuntutan primordial dan membela diri, kognisi rasional (kramadhangsa) margi pratigan atau intuisi altruistik (manungsa tanpa tenger) berupa pemanggih leres (pengertian dan kesadaran nurani) dalam bertindak dan bersikap. Dalam gambaran manusia dengan ukuran yang ke empat tersebut Suryomentaram menilai individu telah memiliki kepribadian ideal yang ia identifikasi dengan madeg pribadi dan windu kencana. Ia sudah terhindar dari konflik internal dan eksternal (mnoten keganggu dening raos-raosipun piyambak).

\section{Konsep Mulur Mungkret dalam Pencapaian Kebahagiaan}

Pada dasarnya, bahagia adalah fitrah atau bawaan alami manusia. Artinya, ia merupakan sesuatu yang melekat dalam diri manusia. ${ }^{29}$ Bahagia sudah

${ }^{27}$ Diskripsi disarikan dan diterjemahkan dengan redaksi penulis dari Grangsang Suryomentaram, Kawruh Jiwa, Jilid II, hlm. 126

${ }^{28}$ Diskripsi disarikan dan diterjemahkan dengan redaksi penulis dari Grangsang Suryomentaram, Kawruh Jiwa, Jilid II, hlm. 111

${ }^{29}$ Murtadha Muthahhari, Fitrah: Menyingkap Hakikat, Potensi, dan Jatidiri Manusia, Jakarta: Penerbit Lentera, 2008, hlm. 31. Dinukil dari JURNAL KOMUNIKA, Vol. 9, No. 1, Januari - Juni 2015 Muskinul Fuad: Muskinul Fuad Psikologi Kebahagiaan Manusia 
seharusnya dimiliki oleh setiap manusia, karena menurut fitrahnya, manusia diciptakan dengan berbagai kelebihan dan kesempurnaan. Manusia adalah makhluk yang paling baik dan sempurna dibanding dengan makhluk lainnya. Hal ini telah dinyatakan oleh Allah dalam Al-Isrâ'/17: 70 sebagai berikut: "Dan sungguh Kami telah memuliakan anak cucu Adam dan Kami angkat mereka di daratan dan lautan, dan Kami telah memberikan rezeki yang baik kepada mereka, dan Kami telah lebihkan mereka dari makhluk-makhluk lain yang telah Kami ciptakan dengan kelebihan yang sempurna”. Kabir Helminski, seorang sufi penerus tradisi Jalaluddin Rumi, menulis tentang manusia sempurna dalam bukunya, The Knowing Heart: A Sufi Path of Transformation. Menurut tokoh ini, sifat manusia sempurna adalah refleksi dari sifat-sifat Tuhan yang sebagian tercermin dalam 99 nama Allah (al-Asma 'al Husna). Kesempurnaan manusia adalah takdir bawaan manusia, yang memerlukan hubungan yang harmonis antara kesadaran diri dan rahmat Ilahi. Itulah capaian kebahagiaan yang sesungguhnya. ${ }^{30}$

Dapat terindikasi bahwa kebahagiaan hidup seseorang dapat dinilai secara objektif (objective happiness) dan subjektif (subjective happiness). Secara objektif, kebahagiaan seseorang dapat diukur dengan menggunakan standar yang merujuk pada aturan agama atau pembuktian tertentu. Rakhmat mencontohkan, misalnya ada seseorang bernama Fulan. Ia menghabiskan waktu mudanya untuk berfoya-foya, termasuk dengan melakukan segala tindakan dosa. Ia tidak pernah mengalami sakit. Ia mengaku sangat bahagia. Benarkah ia bahagia? Menurut ukuran agama, ia dianggap tidak bahagia, karena pada hari akhirat kelak, jika ia tidak segera bertaubat, akan masuk neraka. Dalam bahasa Tasawuf, si fulan ini dikatakan sedang mengalami apa yang disebut dengan istidraj. Artinya ia sedang diberi ujian oleh Allah dengan nikmat (kesenangan) untuk melihat apakah ia sadar atau tidak dengan nikmat yang didapatkannya. Menurut ukuran (pembuktian) rasional, ia juga tidak bahagia, karena lama-kelamaan ia pasti akan kehilangan harta, kesehatan, dan kesenangannya. Secara subjektif, kita dapat mengukur kebahagiaan seseorang dengan bertanya kepadanya dengan singkat apakah ia bahagia atau tidak. ${ }^{31}$ Demikian pula dengan konsep makna hidup.

Pada saat materialisme menjadi panglima, di mana kekayaan, jabatan, dan ketenaran menjadi dewa yang diagung-agungkan, kematian bunuh diri seorang

${ }^{30}$ Erbe Sentanu, Quantum Ikhlas: Teknologi Aktivasi Kekuatan Hati, Jakarta: Elex Media Komputindo, 2008, hlm. 19. Dinukil dari JURNAL KOMUNIKA, Vol. 9, No. 1, Januari - Juni 2015 Muskinul Fuad: Muskinul Fuad Psikologi Kebahagiaan Manusia

${ }^{31}$ Jalaluddin Rakhmat, Meraih Kebahagiaan, Bandung: Simbiosa Rekatama Media, 2008, hlm. 107, Lihat juga tulisan Jalaluddin Rakhmat, Tafsir Kebahagiaan, Bandung: Serambi, 2010. Dinukil dari JURNAL KOMUNIKA, Vol. 9, No. 1, Januari - Juni 2015 Muskinul Fuad: Muskinul Fuad Psikologi Kebahagiaan Manusia. 
aktor hebat peraih Oscar (Robin William) adalah sebuah tragedi kemanusiaan. Kenyataan yang mengenaskan ini meniscayakan adanya redefinisi terhadap ukuran kesuksesan dan kebahagiaan. Dua komponen yang selama ini dianggap sebagai ukuran utama kesuksesan, yaitu kekayaan dan kekuasaan, perlu dilengkapi dengan hal-hal yang lebih mendasar lagi. Ariana Huffington menawarkan empat elemen kesuksesan, yaitu: kesehatan lahiriah-batiniah (well-being), ketakjuban (wonder), kearifan (wisdom), dan sikap memberi (giving). Dalam ukuran baru ini, sukses harus berbanding lurus dengan kebahagiaan. Sukses haruslah sebangun dengan kebermaknaan hidup. Jadi, persoalan setiap manusia adalah bagaimana menemukan kebahagiaan hidup yang sesungguhnya dengan mengisinya dengan hal-hal yang bermakna. ${ }^{32}$

Menurut Bastaman, hidup bermakna adalah gerbang menuju kebahagiaan. ${ }^{33}$ Ia adalah corak kehidupan yang menyenangkan, penuh semangat, bergairah, serta jauh dari rasa cemas dan hampa dalam menjalani kehidupan seharihari. Hal ini terjadi sebagai akibat dari terpenuhinya nilai-nilai dan tujuan hidup yang positif dan benar-benar didambakan. Kehidupan pribadi yang bermakna ditandai oleh adanya aspek-aspek berikut ini pada diri seseorang, yaitu: hubungan antar pribadi yang harmonis, saling menghormati, dan saling menyayangi; kegiatan-kegiatan yang disukai dan menghasilkan karya-karya yang bermanfaat buat orang lain; kemampuan mengatasi berbagai kendala kehidupan dan menganggap kendala ini bukan sebagai masalah, tetapi sebagai peluang dan tantangan; tujuan hidup yang jelas sebagai pedoman dan arahan kegiatan yang dilandasi oleh keimanan yang mantap; rasa humor yang tinggi, yaitu mampu melihat secara humoristis pengalaman-pengalaman sendiri, termasuk pengalaman hidup yang tragis; secara sadar berusaha meningkatkan taraf berpikir; bertindak positif, mengembangkan potensi diri, yang meliputi fisik, mental, emosi, sosial, dan spiritual, secara seimbang, untuk meningkatkan kualitas hidup yang lebih baik dan meraih citra diri yang diidam-idamkan; dan melandasi semua hal yang di atas dengan do'a, ibadah, dan niat yang suci. Aspek-aspek di atas pada dasarnya merupakan turunan dari tiga jenis nilai yang oleh Frankl diyakini bisa menjadi sumber kehidupan yang bermakna, yaitu meliputi: nilai-nilai kreatif atau berkarya (creative values), nilai-nilai penghayatan (experiential values) dan nilai-nilai bersikap (attitudinal values),

${ }^{32}$ Yuswohady, "Meredefinisi Ukuran Sukses", dalam Kompas, Jum'at, 12 Desember 2014. Dinukil dari JURNAL KOMUNIKA, Vol. 9, No. 1, Januari - Juni 2015 Muskinul Fuad: Muskinul Fuad Psikologi Kebahagiaan Manusia.

${ }^{33}$ HD. Bastaman, Integrasi Psikologi dengan Islam, Menuju Psikologi Islami, Yogyakarta: Pustaka Pelajar, 1995, hlm. 196. Dinukil dari JURNAL KOMUNIKA, Vol. 9, No. 1, Januari - Juni 2015 Muskinul Fuad: Muskinul Fuad Psikologi Kebahagiaan Manusia. 
serta ditambah dengan satu jenis nilai yang dikemukakan oleh Bastaman, yaitu nilainilai pengharapan (hopeful values). ${ }^{34}$

Selanjutnya, beberapa komponen atau instrumen kebahagiaan dapat diidentifikasikan secara objektif ke dalam beberapa hal berikut, yaitu: terpenuhinya kebutuhan fisiologis (material), misalnya makan, minum, pakaian, kendaraan, rumah, kehidupan seksual, kesehatan fisik, dan sebagainya; terpenuhinya kebutuhan psikologis (emosional), misalnya, adanya perasaan tenteram, damai, nyaman, dan aman, serta tidak menderita konflik batin, depresi, kecemasan, frustasi, dan sebagainya; terpenuhinya kebutuhan sosial, misalnya memiliki hubungan yang harmonis dengan orang-orang di sekelilingnya, terutama keluarga, saling menghormati, mencintai, dan menghargai; dan terpenuhinya kebutuhan spiritual, misalnya mampu melihat seluruh episode kehidupan dari persepektif makna hidup yang lebih luas, beribadah, dan memiliki keimanan kepada Tuhan. Apabila keempat kebutuhan di atas dapat dipenuhi secara seimbang, dapat dipastikan bahwa seseorang akan merasakan kebahagiaan hidup. Jadi, kata kuncinya adalah pada terdapatnya keseimbangan dalam hidup seseorang.

Para filosof muslim sendiri membedakan adanya tiga tingkatan kebahagiaan, yaitu: Pertama, kebahagiaan yang bersifat badani. Kedua, yang lebih tinggi dan lebih memuaskan, adalah kebahagiaan yang lebih bersifat intelektual, yakni penguasaan ilmu pengetahuan. Ketiga, yang merupakan kebahagiaan puncak (hakiki), adalah kebahagiaan yang bersifat spiritual. Kebahagiaan jenis ini sering disebut pula kebahagiaan yang bersifat Ilahi, sebagaimana dipromosikan kaum Sufi. Sebagian filosof meenyebut kebahagiaan puncak ini dengan peraihan cinta Ilahi. ${ }^{35}$

Akan tetapi hal ini bukan kemudian dipahami bahwa tingkat kebahagiaan yang satu menegasikan pentingnya kebahagiaan yang lain. Di samping tingkatan kebahagiaan di atas, dikenal pula beberapa kategori kebahagiaan yang meliputi: kebahagiaan yang bersifat jangka pendek-panjang, peripheral-ultimate, duniaakihirat, jasmani-ruhani, hakiki-tidak hakiki, dan sebagainya. Lagi-lagi perlu diingat kembali, bahwa pengkategorian ini bukan dalam arti memisahkan secara diametral, tetapi sekadar untuk memudahkan pemahaman dan pengetahuan bagi manusia. Sebagai perbandingan, Ibn Miskawaih merinci tanda-tanda orang yang berbahagia sebagai berikut: penuh energi, optimis, penuh keyakinan, tabah dan ulet, murah hati, memiliki sikap istiqamah, dan rela (qanâ'ah). Ciri-ciri ini tidak

${ }^{34}$ HD. Bastaman, Logoterapi: Psikologi untuk Menemukan Makna Hidup dan Meraih Hidup Bermakna, Jakarta: Rajawali Pers, 2007. Dinukil dari JURNAL KOMUNIKA, Vol. 9, No. 1, Januari - Juni 2015 Muskinul Fuad: Muskinul Fuad Psikologi Kebahagiaan Manusia.

${ }^{35}$ Haidar Bagir, Buku Saku Filsafat Islam, Bandung: Mizan, 2005, hlm. 203 
melihat kebahagiaan dari dimensi instrumental (bendawi), tetapi lebih mengacu pada dimensi etis yang berangkat dari nilai-nilai dan akhlak Islam. ${ }^{36}$

Dengan demikian kebahagiaan seseorang dapat dilihat dari tiga sudut pandang. Pertama, secara objektif, yaitu dengan melihat sejauh mana tingkat pemenuhan kebutuhan, baik fisik, psikis, sosial, maupun spiritual pada diri seseorang secara seimbang. Kedua, secara preskriptif (eksternal), yaitu dengan melihat apakah secara etis seseorang memiliki sifat, standar, atau ciri-ciri, sebagaimana diungkapkan oleh Ibn Miskawaih di atas dan tokoh lainnya dengan merujuk pada nilai-nilai agama, seperti adanya sifat pribadi yang penuh energi, optimis, penuh keyakinan, tabah dan ulet, murah hati, memiliki sikap istiqamah, dan rela (qanâ'ah). Ketiga, secara subjektif (internal), yaitu dengan menanyakan kepada seseorang tentang perasaan subjektifnya terhadap kehidupannya. Misalnya, ketika seseorang mengatakan : "Saya merasa bahagia", tentu memiliki perbedaan dengan orang yang mengatakan: "Saya sedih".

Perjalanan peradaban manusia bergerak dari yang sederhana menuju yang canggih, dari yang kecil menuju yang besar, dari yang sedikit menuju yang banyak, dari yang rumit menuju yang gampang, dari yang irrasional menjadi rasional.

Di manapun tempatnya, realitas dan dinamika peradaban manusia bergerak sebagai hasil pergesekan antara dua macam keinginan manusia yakni agar lebih... dan agar tetap.

Manusia memiliki keinginan agar lebih baik, lebih enak, lebih banyak, lebih lengkap, lebih nyaman, lebih makmur, lebih bergengsi, lebih terkenal, lebih puas, lebih bahagia, lebih sempurna, lebih berkualitas,dan lain-lain. Untuk itu perubahan adalah keniscayaan. Jalannya; inovasi, renovasi, rekayasa, eksplorasi hingga eksploitasi yang telah melahirkan modernisasi, globalisasi, industrialisasi, komputerisasi, teknologi informasi, dan telekomunikasi. ${ }^{37}$

Setidaknya ada empat jenis rasa enak yang dialami setiap manusia, yaitu:

\section{a. Senang vs Susah}

Di semesta ini, tidak ada sesuatu yang secara mutlak harus dicari, dihindari, atau ditolak secara mati-matian. Meski demikian, kita tetap saja akan terus berusaha mencari, menghindari, atau menolak banyak hal. Sering kali usaha kita itu terlalu berlebihan, seakan-akan kita bisa menciptakan rasa senang dan menghindari susah selama-lamanya. Yang demikian itu terjadi karena setiap kali kita mempunyai keinginan-baik terhadap datangnya sesuatu yang kita anggap sebagai anugerah atau supaya terhindar dari peristiwa yang kita anggap musibah-

\footnotetext{
${ }^{36}$ Haidar Bagir, Buku Saku Filsafat Islam, hlm. 203.

${ }^{37}$ Ryan Sugiarto, dkk, Suryomentaram, Riwayat, dan Jalan Menuju Bahagia, hlm. 143-144.
} 
pada saat yang sama kita juga berharap, bila keinginan tersebut tercapai akan membuat kita bahagia seumur hidup. Secara bersamaan juga, kita memendam ketakutan, jika yang kita inginkan itu sampai gagal, kita pasti menderita sepanjang masa. Tanpa sadar, kita berhalusinasi terhadap keinginan secara berlebihan. Tentu saja hal semacam itu sangat keliru. Karena faktanya, berjuta-juta manusia di dunia telah dapat mencapai keinginannya, namun mereka hanya senang sesaat dan tak lama kemudian bersedih kembali. Berjuta-juta manusia di dunia juga telah gagal menggapai keinginan, namun mereka hanya bersedih sesaat dan kemudian dapat merasakan senang kembali.

Padahal, bila kita telah mendapatkan apa yang kita inginkan, kita tidak akan puas sampai di situ. Kita akan kembali terobsesi untuk mendapatkan tambahan yang lebih dan lebih lagi. Karena pada dasarnya, keinginan yang sudah kita gapai senantiasa memanjang dan terus mengembang. Artinya, kalau pun kita merasa senang saat mendapatkan sesuatu, kesenangan itu hanya berlangsung sesaat karena kita akan kembali digelisahkan oleh keinginan baru yang menjadi perpanjangan dan pengembangannya. Begitu perpanjangan keinginan kita itu sampai pada suatu titik yang tak mungkin lagi kita capai maka sedihlah perasaan kita.

Pada saat yang sama, ketika kita merasa mentok karena tak mungkin lagi menggapai keinginan kita, secara otomatis keinginan kita akan menyusut. Ketika penyusutan keinginan kita itu akhirnya sampai pada titik yang mungkin kita dapatkan kembali maka perasaan sedih kita pun dengan sendirinya menghilang dan kita kembali bisa merasakan senang.

Contoh, ketika kita ingin mendapatkan seorang istri atau suami, yang kita pilih tentu yang berwajah rupawan, masih perawan atau perjaka, kaya, keturunan bangsawan, terpelajar, berbakti, cermat, cinta keluarga, dan seterusnya.

Namun, apabila daftar keinginan kita itu tak terpenuhi, apakah kita akan berduka selama-lamanaya? Ternyata tidak. Kita memang akan bersedih, tetapi tidak akan berlangsung lama karena keinginan kita yang kemudian memendek berkata, "Walaupun syarat pilihanku tidak terpenuhi semua, asal saja wajahnya rupawan, tidak masalah ..." Jika yang cantik atau ganteng tidak kita dapatkan, keinginan kita pun memendek lagi, "Walaupun tidak rupawan, asal saja masih perawan atau perjaka, mungkin oke ...." Apabila ini pun tidak berhasil, keinginan kita pun kembali memendek, "Walaupun sudah janda atau duda, asal saja belum punya anak, ya, tak apalah ...." Jika pilihan ini masih juga gagal, keinginan kita pun akan jadi lebih pendek, "Walaupun banyak anaknya, asal ia tidak cacat, bagiku bukan sebuah persoalan." Apabila keinginan ini pun tidak juga terpenuhi, keinginan kita pun semakin menyusut dan akhirnya berkompromi dengan 
kenyataan, "Kasihan, meski cacat, toh dia adalah manusia sepertiku juga, aku bersedia menikahinya."

Padahal jika dalam mencari istri atau suami hanya dengan syarat asal sama-sama manusia, pastilah tidak menyulitkan kita, bukan? Setidaknya waktu kita menikmati indahnya pernikahan akan lebih panjang karena kita tidak perlu menunggu lama untuk memilih sampai harus menjadi perjaka atau perawan tua.

Sesungguhnya, rasa senang atau susah kita itu sangat relatif. Biasanya, rasa senang kita disebabkan oleh keinginan yang tercapai, sementara keinginan kita yang tercapai akan selalu memanjang melahirkan keinginan-keinginan baru yang kembali membuat susah dan derita. Dan kesusahan kita itu ternyata juga hanya disebabkan oleh keinginan yang tidak tercapai, sedang keinginan yang tidak tercapai otomatis akan memendek sehingga menjadi mudah digapai dan menimbulkan rasa senang lagi. Karena sifat keinginan yang sesekali memanjang (mulur), tak lama kemudian memendek (mungkret) maka rasa hidup seluruh manusia di dunia ini sejak dahulu kala pasti bersifat demikian. Yakni sebentar senang sebentar susah, sebentar susah sebentar senang. ${ }^{38}$

Ketika Sukarno dan Hatta memproklamirkan kemerdekaan Indonesian 1945 yang lalu, ada dua hal yang ada di dalam pikiran mereka, yakni kebebasan dan kemakmuran. Keduanya menjadi mimpi besar, tidak hanya untuk mereka berdua, tetapi juga untuk para bapak bangsa lainnya, seperti Sutan Sjahrir, Muhammad Yamin, dan sebagainya. Dengan kebebasan di tangan, bangsa Indonesia lalu mulai bisa membangun dirinya ke arah keadilan dan kemakmuran bagi semua warganya. Kebebasan dianggap sebagai jembatan emas menuju masyarakat yang paripurna. (Latif, 2011).

Sebagai pribadi, kita tentu juga ingin bebas. Kita ingin bisa menentukan hidup kita sesuai dengan keinginan kita. Kita juga ingin hidup aman, bebas dari rasa takut dan cemas atas hal-hal di luar diri kita. Keinginan untuk bebas tertanam secara alamiah di dalam jiwa manusia.

Penelitian yang dilakukan Institut für Gesellschafts politik di Jerman menunjukkan satu hal, bahwa kebebasan (Freiheit) merupakan nilai tertinggi di dalam masyarakat Jerman sekarang ini. (Reder, et.al, 2014) Hidup tak ada artinya, jika tidak ada kebebasan. Seluruh sistem politik dan ekonomi Jerman memang dirancang untuk bisa menampung cita-cita kebebasan semacam ini. Tentu, tidak ada sistem yang sempurna yang tidak lagi membutuhkan refleksi ulang.

Kebebasan dianggap berharga, setidaknya karena dua hal. Pertama, kebebasan, seperti pandangan Sukarno dan Hatta, adalah jalan menuju citacita yang lebih tinggi, seperti keadilan dan kemakmuran. Selama suatu bangsa

${ }^{38}$ Muhaji Fikriono, Puncak Makrifat Jawa Pengembaraan Batin Ki Ageng Suryomentaram, Jakarta: Penerbit Noura Books (PT Mizan Publika), 2012, hlm. 271-273. 
masih hidup dalam penjajahan, ia tidak akan bisa merasakan keadilan dan kemakmuran. Selama orang masih hidup dalam penjajahan tradisi ataupun tirani "kata masyarakat", ia tidak akan pernah mencapai kebahagiaan.

Kedua, kebebasan juga dianggap sebagai sesuatu yang bernilai pada dirinya sendiri. Kebebasan bukanlah alat untuk mencapai tujuan lain. Sebaliknya, kebebasan adalah tujuan itu sendiri. Pandangan semacam ini mengakar amat dalam di dalam masyarakat Eropa dan AS sekarang ini. Tanpa kebebasan, manusia belumlah sungguh menjalani hidupnya. ${ }^{39}$

Belajar dari Anthony de Mello di dalam bukunya yang berjudul Awareness, A de Mello Spirituality Conference in His Own Words, kebebasan batin dapat dipahami sebagai kebebasan dari keterkondisian batin, atau kebebasan dari "program-program" batin kita. (De Mello, 1990) Sedari kecil, kita diajar bagaimana cara berpikir, cara merasa, dan cara bertindak. Kita menelan semua itu, tanpa sikap kritis, dan kini menjadi bagian dari diri kita. Semua "program" ini lalu menjadi pola hidup kita. Ketika kita mendapat masalah, kita lalu merasa, berpikir dan bertindak sesuai dengan "program" yang kita punya. ${ }^{40}$

Kondisi seseorang akan merasa senang jika menghadapi objek atau stimulus yang menurut konsep yang telah ada adalah baik atau dinilai baik. Jika seseorang senang atau susah hanya jika menghadapi objek tertentu di luar dirinya. Dengan demikian susah atau senang ada hanya jika ada objek di luar diri individu dan tergantung pada konsep baik-buruk yang diterima secara umum. Seneng itu bukan bahagia. ${ }^{41}$

Ketika kita mengalami hal baik, kita pun merasa, berpikir dan bertindak sesuai dengan "program" tersebut. Bahkan, pemahaman kita tentang apa itu "masalah" dan apa yang merupakan "berkah" juga ditentukan oleh "program" yang kita terima dari masyarakat kita, dan kita telan mentah-mentah begitu saja. Kita pun melihat dunia tidak dengan apa adanya dunia itu, tetapi dengan "program" yang kita punya. Segala bentuk perasaan, seperti sedih, senang, marah, dan sebagainya, adalah "program" hasil dari bentukan masyarakat kita. Misalnya, ketika seseorang meninggal, kita "diajarkan" oleh masyarakat kita untuk sedih.

Ketika mendapat bonus dari perusahaan, kita "diajarkan" untuk menjadi senang, bahkan mengadakan pesta dengan keluarga dan sahabat. Emosi dan perasaan, serta cara kita memaknai dan menanggapi berbagai peristiwa dalam hidup kita, bukanlah sesuatu yang alamiah, melainkan bentukan dari masyarakat kita. Jadi, ketika kita sedih, bukan karena suatu peristiwa membuat kita sedih, tetapi karena kita "diajarkan" untuk sedih, ketika mengalami peristiwa semacam

${ }^{39}$ Reza A.A Wattimena, Bahagia, Kenapa Tidak?, hlm. 68.

${ }^{40}$ Reza A.A Wattimena, Bahagia, Kenapa Tidak?, hlm. 70.

${ }^{41}$ Ryan Sugiarto, dkk, Suryomentaram, Riwayat, dan Jalan Menuju Bahagia, hlm. 145. 
itu. Dan sebaliknya, ketika kita senang, bukan karena suatu peristiwa membuat kita senang, tetapi karena kita "diajarkan" sejak kecil untuk merasa senang, ketika mengalami peristiwa tersebut. Inilah yang disebut sebagai "program" yang membuat seluruh batin kita tidak bebas untuk memahami dunia apa adanya. De Mello bahkan menyebutnya sebagai proses cuci otak, bahkan hipnosis. Apa yang diajarkan oleh De Mello dan Bordt adalah inti dari kebebasan itu sendiri, yakni kebebasan batin. ${ }^{42}$

\section{b. Rasa Sama}

Pada dasarnya, setiap manusia memiliki keinginan yang sama, yaitu keinginan yang sewaktu-waktu memanjang dan sewaktu-waktu memendek. Kesamaan tersebut dapat digunakan untuk membuat generalisasi bahwa seluruh umat manusia di dunia ini, sejak bayi hingga menjadi tua renta sama-sama bersifat sewaktu-waktu senang dan sewaktu-waktu susah. Dapat dipastikan bahwa hakikat rasa manusia secara universal sesungguhnya sama saja. Orang kaya atau miskin, rakyat atau pejabat, orang suci atau penjahat, rasa hidupnya pasti sama, yaitu sebentar susah dan sebentar senang. Masing-masing dari kita sebagai manusia, sama-sama memiliki rasa senang-susah, lama-cepat, dan berat-ringan, yang berbeda hanya pada faktor yang membuat susah dan senang.

Hal itu bergantung dari latar belakang orang tersebut. Misalnya, orang kaya akan merasa senang karena mampu mendirikan pabrik baru, sementara orang miskin akan kegirangan karena medapatkan sebungkus nasi lengkap dengan lauk pauknya di hari itu. Meski tampaknya jauh berbeda, namun hakikat rasa senang atau kesenangan yang dirasakan kedua orang tersebut sama saja. Seorang presiden merasa senang karena dapat terpilih kembali pada pemilu, sedangkan seorang kuli bangunan bergembira karena masih bisa bekerja di proyek yang baru. Keduanya sama di dalam merasakan senang. Orang suci merasa senang bila berbagai nasihatnya diikuti, penjahat merasa senang ketika tidak lagi diuber-uber polisi. Baik orang suci maupun penjahat, keduanya sama di dalam merasakan senang.

Akan tetapi, orang miskin sering kali mengira bahwa orang kaya itu tidak pernah susah. Perkiraan yang demikian itu tentu saja keliru sebab dalam diri orang kaya juga berisi banyak keinginan yang bila tercapai masih akan terus memanjang. Misalnya, pengusaha transportasi yang sudah memiliki perusahaan taksi dengan jumlah armada ratusan ribu dengan puluhan pool yang tersebar di berbagai kota. Meskipun perusahaan taksinya sudah berkembang pesat, keinginannya tetap memanjang. Ia ternyata ingin menguasai perusahaan bus kota. Setelah berhasil menguasai perusahaan bus kota, keinginannya pun bertambah panjang. Ia ingin

\footnotetext{
${ }^{42}$ Reza A.A Wattimena, Bahagia, Kenapa Tidak?,hlm. 71.
} 
memiliki armada pesawat terbang. Namun sebelum keinginan barunya tercapai, tiba-tiba ada pengusaha transportasi lain yang memiliki reputasi internasional mendirikan perusahaan taksi di dalam negeri, ia pun merasa susah karena khawatir kalau perusahaan taksinya tersaingi dan akan kalah dalam berkompetisi. Artinya, orang sekaya apa pun, rasa hidupnya tentu sebentar senang sebentar susah, sebentar susah sebentar senang, begitu seterusnya.

Sebaliknya, orang kaya juga sering salah dalam menghayati rasanya orang miskin. Orang kaya mengira bahwa orang miskin itu selalu menderita dan susah selama-lamanya. Penilaian semacam itu terjadi karena subjektivitas orang kaya yang ketakutan kalau sampai menjadi miskin. Apabila penilaian orang kaya terhadap orang miskin dapat objektif, ia pun dapat memahami bahwa si Miskin juga tidak selamanya susah. Oleh karena itu, orang miskin yang menyangka bahwa orang kaya itu dapat bahagia dan senang selamanya, juga terjadi karena rasa subjektif orang miskin yang berkeinginan untuk menjadi kaya. Jika orang miskin dapat menggunakan objektivitasnya dalam memandang orang kaya, ia dapat dengan mudah memahami bahwa si Kaya juga ternyata tidak senang selamanya. Demikian pula orang suci sering kita kira tidak pernah susah. Perkiraan demikian itu pun sangat keliru karena dalam diri orang sucipun berisikan keinginan. Ketika nasihat-nasihatnya di dengar banyak orang, tentu dirinya menjadi senang.

Namun, ketika apa yang dia sampaikan tidak diikuti, tentu sedihlah dia. Misalnya, orang suci memberikan nasihat, "Tinggalkanlah keburukan dan berhijrahlah kepada kebaikan.” Karena kita merasa bahwa istri atau suami kita perangainya sangat buruk, lalu kita meninggalkan rumah dan mencari wanita atau pria di luar rumah yang kita anggap lebih baik. Jika orang suci itu tahu bahwa kita berbuat demikian setelah mendengar nasihatnya, tentu akan berganti rasa senangnya. Itu artinya, sebaik apa pun perilaku orang-orang suci, mereka juga akan tetap mengalami sedih dan senang secara bergantian. Jika kita telah memahami sepenuhnya bahwa rasa orang di seluruh dunia sama saja, yakni sebentar senang, sebentar susah maka terbebaslah kita dari neraka iri hati dan sombong. ${ }^{43}$

\section{c. Iri Hati dan Sombong}

Secara sederhana, iri hati ialah merasa dikalahkan atau dilebihi oleh orang lain. Adapun sombong menjadi kebalikannya, yaitu merasa dapat mengalahkan atau melebihi orang lain. ${ }^{44}$

${ }^{43}$ Grangsang Suryomentaram, Kawruh Jiwa Jilid 1, Jakarta, CV Haji Masagung 1989. hlm. 14-15. Dinukil dari buku Muhaji Fikriono, Puncak Makrifat Jawa Pengembaraan Batin Ki Ageng Suryomentaram, Jakarta: Penerbit Noura Books (PT Mizan Publika), 2012, hlm. 273-275.

${ }^{44}$ Grangsang Suryomentaram, Kawruh Jiwa Jilid 1, hlm. 15-19. Muhaji Fikriono, Puncak Makrifat Jawa Pengembaraan Batin Ki Ageng Suryomentaram, Jakarta: Penerbit Noura Books (PT Mizan Publika), 2012, hlm. 276-281. 
Perasaan iri hati dan sombong inilah yang membuat kita sering kali berusaha secara mati-matian hingga tak tahu batas kemampuan yang kita miliki. Tiga hal yang paling kita prioritaskan demi memenuhi tuntutan kedua perasaan itu adalah kekayaan (semat), kedudukan (drajat), dan kekuasaan (kramat). Ketika kita tengah diperbudak oleh iri hati dan sombong, sadar atau tidak perasaan kita berbisik, "Sebaiknya kucari uang sebanyak-banyaknya agar bisa menjadi kaya melebihi orang itu, dan jangan sampai miskin terus seperti orang ini. Sehingga, aku dapat menghina orang itu dan tidak selalu menerima ejekan seperti ini. Aku juga harus mendapatkan kedudukan yang tinggi supaya lebih mulia dibanding orang itu, dan jangan sampai dihina lagi seperti sekarang ini. Aku juga harus mendapat kekuasaan yang lebih besar, supaya berkuasa dan bisa menaklukkan orang itu. Aku sudah bosan menjadi lemah dan dipecundangi olehnya seperti ini." Sedemikian berat beban perasaan ini, hingga kita lebih baik mati jika tak mencapai tujuan.

Perkataan, "Lebih baik aku mati jika tidak dapat mencapai tujuan," jika sering terlintas dalam pikiran, akan mempercepat kita kehilangan akal sehat. Sehingga kita yang biasanya bersikap rasional dan bahkan sangat religius, dengan mudah bisa tergiur oleh iklan paranormal yang senantiasa tampil glamor dan sering nampang di televisi. Dan kepada dukun yang telah menjerat kita dengan pencitraan itu, kita justru meminta petunjuk, "Bagaimana, Mbah, hidup saya ini mengapa selalu dirundung kemalangan. Apakah memang nasib saya harus dibenci orang? Sebaiknya saya harus bagaimana?" Maka, jika dukun itu meminta, "Sanggupkah Anda bertapa dengan ditanam di tanah selama empat puluh hari? Memang berat melaksanakan tapa ini, tetapi bila dijalani, tentu nasibmu akan menjadi lebih baik."

Tentu saja pikiran kita semakin gelap. Akan tetapi, karena telah menjadi budak si Iri Hati dan si Sombong, kita pun menyanggupi, "Baik, Mbah. Saya bersedia ditanam asal benar-benar bisa mendapat anugerah. Toh andai pun saya gagal dan mati, hal itu tetap lebih baik daripada hidup, tetapi menjadi buah hinaan para tetangga seperti sekarang ini." Begitu disiapkan lubang atau kubangan, tibatiba nyali kita menciut, "Mbah, jika penguburan ditangguhkan dulu sampai saya benarbenar siap, apakah boleh?”

Jika kita memahami bahwa hakikat rasa orang di seluruh dunia itu sama, pandangan kita menjadi terang. Kita pun kembali dapat bersikap rasional bahwa orang yang ditanam selama empat puluh hari, pasti akan mati karena tidak dapat bernapas. Orang yang dibekap kurang dari sepuluh menit saja sudah kehabisan napas, apalagi harus ditanam di dalam tanah selama empat puluh hari tanpa sirkulasi udara.

Hal yang paling diidamankan oleh orang yang iri hati dan sombong adalah asal dapat mengungguli orang lain dalam segala hal. Dalam hal makanan, pakaian, 
tempat tinggal, keluarga, anakanak, dan sebagainya, ia selalu ingin melebihi siapa saja. Sementara, orang lain pun sama-sama ingin menyaingi atau melebihi orang selain dirinya. Oleh sebab itu, ketika berjuta-juta manusia telah diperbudak oleh perasaan iri hati dan sombong, tindakan antara satu sama lain akan saling unggul mengungguli hingga semua akan jatuh ke bawah. Bila dalam usaha untuk melampaui orang lain ia tergelincir, sehingga dapat dilampaui orang lain maka hatinya menjadi kesal, "Baik, meskipun aku kalah, tetapi tetanggaku itu hidupnya merana. Itu sudah cukup membuatku senang." Padahal, sikap tetangganya juga berpikir demikian, yakni berusaha menyusahkan orang lain. Maka, berjutajuta manusia yang sama sama terserang virus iri hati dan sombong tadi, selalu bertindak hanya untuk saling menyusahkan satu sama lain.

Pandangan orang yang iri hati dan sombong terhadap segala sesuatu dan peristiwa juga sering terbolak-balik. Misalnya, ketika ingin memiliki mobil karena keinginannya sangat menggebu sampaisampai ia merasa, "Jika aku tidak sanggup memiliki mobil pribadi, alangkah menderitanya batinku. Kalau barang-barang yang lain, aku tidak begitu peduli." Maka, jika ia menjumpai seseorang yang mengendarai mobil, apalagi pengendara mobil itu adalah tetangga yang dibenci dan hendak dilebihinya maka begitu mendengar bunyi klaksonnya saja, ia sangat kesal, seakan-akan jantungnya copot. Begitu pulang ke rumah, semalam suntuk, ia tak bisa tidur karena memikirkan tetangganya yang berhasil memiliki mobil lebih dulu, "Kalau hanya mobil kredit, dari dulu aku juga sudah punya, dasar tak punya malu!" Demikian kira-kira pandangan orang yang iri hati. Keadaan itu selalu terjadi terbolak-balik hanya disebabkan oleh rasa iri hati dan sombong. Bila dipahami, apakah benar tetangganya itu ketika membunyikan klakson adalah sengaja pamer kepadanya? Apakah benar, hal itu dilakukan agar ia gelisah sepanjang malam karena merasa telah dikalahkan? Lalu dari mana pula ia tahu bahwa tetangganya membeli mobil dengan cara kredit?

Dampak dari pandangan terbolak-balik yang disebabkan rasa iri hati dan sombong itu memang sangat dahsyat. Hingga tak jarang hal itu dapat membuat orang membenci suami atau istrinya di rumah hanya lantaran sempat berpapasan dengan pria tampan atau wanita cantik di jalan. Korban yang sangat memprihatinkan dari rasa iri dan sombong ini adalah ketika ia sampai menggerutu sendiri, "Setelah kupikir-pikir, suami atau istriku ini memang kelewatan. Sudah jelek wajahnya, buruk pula hatinya. Kalau sekarang bisa berjodoh denganku, dulunya pasti memakai guna-guna sehingga aku sampai terpikat kepadanya." Padahal pria tampan atau wanita cantik yang berpapasan dengannya di jalan tersebut, tentu tak punya maksud agar ia membenci suami atau istrinya.

Rasa iri hati dan sombong juga dapat membuat pandangan seseorang menjadi gelap. Tak peduli sudah punya anak dan cucu, ia tetap saja tidak dapat 
menikmati rasa bersuami-istri yang membahagiakan. Karena, setiap kali menjumpai suami atau istrinya sendiri, yang dirasakannya justru suami atau istri orang lain, "Si Anu itu hidupnya sungguh bahagia karena mempunyai suami atau istri yang menyenangkan, perhatian, setia, dan pintar. Berbeda sekali dengan diriku yang merana ini, mempunyai suami atau istri yang sangat galak, gampang marah, dan tidak romantis."

Hanya orang-orang yang sudah terlepas dari siksa neraka iri hati dan sombong yang dapat memasuki surga ketenteraman. Di dalam surga ketenteraman itu ia baru dapat menasihati dirinya sendiri, "O, bagaimana ini? Berumah tangga kok ribut terus. Bukankah landasan yang benar dalam membina setiap hubungan, apalagi pernikahan, adalah saling membahagiakan pendamping hidup?"

Kebanyakan pasangan suami istri memang telah keliru dalam memberikan landasan terhadap hubungan mereka. Pihak yang bermaksud menikahi beranggapan, "Kalau dia menjadi istri atau suamiku, pasti akan senang hidupnya." Anggapan demikian itu sebenarnya tidak memerhatikan rasa calon pendamping hidup. Apakah dia memang bahagia saat berjodoh dengannya? Hal itu sungguh tidak pernah menjadi bahan pertimbangan. Karena sesungguhnya yang ia kejar adalah kenikmatannya sendiri. Begitu pun dengan calon yang hendak dinikahi. Ketika bersedia menikah dengannya juga memendam maksud mencari kenikmatan diri sendiri, "Aku bersedia menikah dengannya supaya hidupku nanti bisa begini."

Berbagai perselisihan yang timbul di dunia ini memang selalu disebabkan penghayatan rasa yang dibolak-balik sendiri. Hal itu berlangsung pada rasa diri sendiri maupun rasa orang lain. Bahkan, semakin rapat sebuah hubungan, semakin tajam pula muncul perselisihan. Relasi intim suami-istri adalah contoh yang paling nyata. Ketika masing-masing pihak tertutupi oleh kepentingan sendiri-sendiri dalam menjalin hubungan maka perceraian atau perpisahan, bahkan permusuhan hanya soal menunggu waktu saja. Apalagi jika rasa iri hati dan sombong turut campur. Ditambah dengan pemahaman yang gelap bahwa hakikat rasa hidup adalah sebentar senang sebentar susah, lengkap sudah penderitaan kita. Sebelum masing-masing pihak yang menjalin hubungan terbebas dari rasa iri hati dan sombong, ia tidak akan pernah bisa memahami bahwa dalam relasi sedekat apa pun, rasanya tentu juga sebentar nikmat sebentar tidak nikmat.

Berbeda dengan orang yang sudah berada di dalam surga ketenteraman. Ia terbebas dari segala kewajiban yang memang seharusnya tidak menjadi beban. Artinya, seseorang tidak akan pernah melaksanakan segala sesuatu dalam keterpaksaan. Kebiasaan orang-orang yang mewajibkan bermacam-macam hal yang bersumber dari anggapan-anggapan, katanya-katanya, pantasnya-pantasnya, dan duga-duga kepada diri sendiri adalah orang yang masih duduk di neraka. 
Orang yang demikian biasanya berpandangan, "Orang hidup itu harus begini, untuk itu saya harus begini, pakaian harus begini, rumah harus begini, hubungan suamiistri harus begini, mendidik anak harus begini, anak-anak juga harus begini, terhadap pembantu harus begini, terhadap tetangga harus begini, dan begitu seterusnya." Bagi yang telah menduduki ketenteraman surga, hal itu tidak berlaku lagi baginya.

Sekali lagi, apabila kita memahami dengan jujur, bahwa hakikat rasa manusia di seluruh dunia sama saja maka kita terbebas dari penderitaan neraka iri hati dan sombong kemudian dengan mudah dapat memasuki surga ketenteraman. Di dalam surga ketenteraman, kita tidak lagi diperbudak oleh apa dan siapa pun termasuk oleh rasa-rasa kita sendiri. Sehingga kita dapat dengan leluasa bertindak apa saja semau kita tanpa menjadi beban dan tidak membebani sesama. Karena batas hak kebebasan kita untuk melakukan segala tindakan di dalam surga ketenteraman, adalah dengan mengakui dan menjunjung tinggi hak kebebasan orang lain. Dalam surga ketenteraman inilah kita dapat merasakan hakikat rasa hidup yang sebenar-benarnya, yakni sebentar senang sebentar susah, sebentar susah sebentar senang.

\section{d. Imunitas Manusia}

Sebagaimana telah kita pahami bersama bahwa sifat keinginan yang ada pada diri kita sebentar memanjang dan sebentar memendek, sedangkan rasa yang ditimbulkan adalah sebentar senang dan sebentar susah. Sejak zaman dahulu, sekarang, dan sampai kapan pun pada dasarnya sifat dan rasa yang ditimbulkan keinginan kita selalu ajeg (konstan), yakni sebentar memanjang dan sebentar memendek; menimbulkan rasa sebentar senang dan sebentar susah. ${ }^{45}$ Dengan demikian, keinginan (karep) kita itu dapat kita anggap serupa atau mirip Barang Asal. Ya, ketika kita masih berada dalam kandungan ibu, keinginan kita sesungguhnya sudah ada, walaupun kini kita tak dapat lagi mengingat. Nanti setelah kita mati, raga kita membusuk, bisa jadi keinginan kita akan tetap ada. Setidaknya dalam bayangan kita saat ini, kalau kita mati kelak ingin berada di dalam Surga yang kekal penuh kenikmatan dan tidak pernah mengalami kesedihan, misalnya.

Sebagai sesuatu yang mirip (kuasi) Barang Asal, dalam kehidupan nyata yang kita alami sekarang ini, keinginan benar-benar telah menunjukkan kedigdayaannya. Meskipun ia dihancurkan melalui kesusahan, penderitaan, rasa malu, dan lain sebagainya, sifat keinginan tetap tidak berubah. Begitu pun saat ia

${ }^{45}$ Grangsang Suryomentaram, Kawruh Jiwa Jilid 1, hlm. 22-27. Muhaji Fikriono, Puncak Makrifat Jawa Pengembaraan Batin Ki Ageng Suryomentaram, Jakarta: Penerbit Noura Books (PT Mizan Publika), 2012, hlm. 281-285. 
berusaha disuap dengan berbagai kesuksesan pencapaian dan beragam prestasi, keinginan tetap bergeming. Keinginan selalu saja sebentar memanjang (mulur), sebentar memendek (mungkret). Akan tetapi, bagi yang memahami hakikat keinginan, akhirnya menjadi imun terhadap rasa yang menyertai. Ketika rasa kita telah memiliki kekebalan terhadap memanjang dan memendeknya keinginan secara konstan, selesai sudah perjalanan hidup kita sebelum ajal tiba. Artinya kita telah resmi mendapat sertifikat atau tanda kelulusan dalam perjalanan mengarungi ombak samudra hidup.

Manusia yang belum mendapatkan sertifikat hidup, akan selalu dihantui berbagai penyesalan atau kesedihan dan senantiasa dibayang-bayangi oleh ketakutan dan kekhawatiran. Secara sederhana dapat definisikan, bahwa sesal dan sedih adalah penderitaan yang telah terjadi, sedangkan khawatir adalah rasa takut menderita terhadap kejadian yang belum dialami. Menyesal dan khawatir inilah yang menyebabkan orang bersedih hati, prihatin, sengsara, hingga merasa celaka, gagal, menderita, dan tidak prospektif.

Ungkapan, "Kalau saja dulu aku memilih yang itu, tentu aku sangat bahagia dan tidak menderita seperti ini," adalah ekspresi penyesalan seseorang yang takut akan pengalaman masa lampau yang menyebabkannya jatuh celaka, menjadi susah, miskin, terhina, dan merasa tak berdaya. Apabila orang memahami dan menyadari bahwa setiap manusia sesungguhnya memiliki kekebalan atas segala rasa, ia pun menasihati dirinya sendiri, "Andaikan jarum waktu dapat diputar kembali, bagaimana pun keadaanku dahulu, pasti rasanya juga akan sebentar senang sebentar susah seperti ini." Jika demikian kesadaran yang muncul, seluruh penyesalan tentang masa lalu akan lenyap dengan mudah. Akan tetapi, jika ia tidak kunjung memahami adanya imunitas di dalam dirinya, penyesalan akan terus berlangsung, berlarut-larut hingga ketakutannya menjadi kian tak terkendali.

Seperti takut terkutuk dan takut durhaka, hingga ekspresi penyesalannya menjadi, "Seandainya dahulu aku tidak terkutuk oleh si Anu, atau tidak durhaka pada si Ano, tentu aku sudah bahagia dan tidak celaka seperti sekarang ini." Namun, jika ia paham bahwa dirinya kebal, ia pun dapat menyadari, "Walaupun dulu saya terkutuk atau tidak, durhaka atau tidak, tetap saja rasanya sebentar senang sebentar susah." Jika hal itu disadari pasti seluruh penyesalan akan lenyap.

Begitu pun kekhawatiran atau ketakutan terhadap pengalaman yang belum dialami. Hal itu hanya akan membuahkan kegelisahan dan penderitaan. Dirinya selalu cemas jika di kemudian hari akan celaka, susah selamanya, terperosok di lembah kemiskinan, menjadi terhina, tak berdaya, tidak bahagia, dan lain sebagainya. Setelah orang memahami bahwa dirinya memiliki imunitas, ia pun menasihati dirinya, "Walaupun kelak akan terjadi apa saja seperti bumi dan 
langit akan merapat, rasanya pasti sebentar senang sebentar susah.” Lalu, sirnalah seluruh kekhawatirannya. Jika ia tak juga memahami, kecemasan akan semakin berlarut-larut sehingga takut akan hal yang aneh-aneh seperti takut terkutuk, takut durhaka, takut tidak bahagia dan sebagainya.

Padahal apa yang disebut sebagai terkutuk maupun durhaka tersebut tidak pernah sungguh-sungguh ia pahami. Sungguh aneh. Namun, apabila ia memahami bahwa manusia memiliki imunitas, ia segera menyadarkan dirinya, "Mana ada orang terkutuk atau durhaka? Kalau toh ada, rasanya pasti hanya sebentar senang sebentar susah." Jika kekhawatiran itu dibiarkan berlarut-larut, ia akan takut kepada hal-hal yang semakin aneh seperti mati tersesat. Masa orang mati bisa tersesat? Akan tetapi, bila mengerti bahwa manusia itu memiliki imunitas, dapatlah ia menasihati dirinya, "Bagaimana mungkin orang mati dapat tersesat? Kalau tersesat tentu kembali hidup seperti yang kita alami sekarang ini. Lagi pula jika ada mati tersesat, berarti ada pula hidup tersesat? Apakah ketika hendak hidup dahulu kita sempat bertanya nanti aku harus bagaimana? Bukankah saat kita lahir tidak berbekal apa-apa? Bukankah kita menjelma sebagai manusia begitu saja? Hidung sebagai sarana penciuman tepat di atas mulut, telinga yang berfungsi untuk mendengar tepat di kedua sisi kepala; kepala kita di atas, kaki di bawah, perut di depan, begitu seterusnya. Semua itu tiba dan menyertai kita begitu saja, bukan?" Menyesal dan khawatir itu sesungguhnya didasari oleh satu anggapan bahwa manusia itu dapat senang atau susah selama-lamanya. Apabila demikian logika kita maka dengan mati-matian rasa senang dikejar, dan dengan mati-matian pula rasa susah ditolak atau dihindari.

Kita tak sadar, hal itu menimbulkan ketakhayulan dalam diri. Takhayul ialah menghubung-hubungkan sebab dan akibat yang sebenarnya tidak ada hubungan sama sekali. Sebagai contoh, orang yang sedang sial saat berdagang lalu berucap, "Kesialan ini tentu lantaran aku tidak membakar kemenyan dan tidak sembahyang malam Jumat kemarin, sehingga daganganku tidak laku." Jelas, membakar kemenyan dan bersembahyang itu tidak ada sangkut paut dengan kesialan seseorang dalam berdagang. Akan tetapi, karena kita dijejali pikiran takhayul Maka kita pun mencoba mencari-cari hubungannya.

Contoh lain yang lebih jelas, seorang anak tengah bermain, tibatiba sakit kejang-kejang, kemudian orangtuanya berkata, "Anak itu pasti dijegal oleh jin penunggu jalan perempatan hingga badannya kejang-kejang." Padahal jelas, anak sakit kejang tidak bersangkutpaut dengan jin penunggu jalan. Karena untuk menjelaskan apakah jin itu berkaki dua atau berkaki empat, bertelur atau menyusui, juga tak ada seorang pun yang tahu. Namun, tetap saja ada yang percaya bahwa ada jin yang iseng menjegal anak kecil yang sedang bermain-main di jalanan. 
Ketakhayulan semacam itu menyebabkan orang melakukan ritual dan berpantang yang aneh-aneh. Seperti merendam diri selama satu jam dalam tempo empat puluh hari, dengan asumsi bahwa jika setiap malam merendam diri sambil mengucapkan mantra-mantra tertentu, dalam waktu empat puluh hari pasti memperoleh karunia kebahagiaan untuk selama-lamanya. Jika ia memahami bahwa sebagai manusia ia telah memiliki imunitas, pandangannya menjadi jernih. Ia akan tahu bahwa hasil dari orang merendam diri selama itu hanyalah menggigil kedinginan dalam kesepian. Bahkan istri atau suami yang ditinggalkan di rumah pun ikut merasa sepi dan kedinginan bahkan tidak dapat tidur karena menanti-nanti. Ditambah dengan tindakannya berpantang yang aneh-aneh seperti pantang makan dan pantang tidur, semakin kacaulah jalan pikirannya. Bukankah nikmatnya orang lapar adalah ketika makan, dan bahagianya orang mengantuk adalah saat tidur pulas. Aneh, bukan? Orang itu memantang hal-hal yang nikmat dan membahagiakan, namun selalu mengeluh bahwa tidak pernah merasakan kenikmatan serta kebahagiaan dalam hidupnya.

Pantangan aneh-aneh itu kalau diteruskan, akan berlarut-larut hingga berpantang berdekatan dengan suami atau istri sendiri. Bahagiakah rasa yang berpantang maupun yang dipantang? Pastilah tidak. Oleh karena itu, ketika baru berpantang berjalan seminggu, misalnya, jika tak diawasi diam-diam sudah saling menyerobot. Sekali lagi, jika orang memahami bahwa manusia itu memiliki imunitas dalam dirinya, pandangan menjadi jernih. Ia pun memahami bahwa hasil berpantang untuk berhubungan seksual dengan istri atau suami sendiri adalah tidak nyaman. Demikian sifat katakhayulan yang mendorong orang melakukan ritual dan berpantang macam-macam, hanya karena memiliki anggapan akan adanya kesenangan atau kesusahan abadi.

\section{E. Penemuan Teori Kawruh Jiwa}

Kawruh jiwa Suryomentaram merupakan serangkaian ajaran yang berupa wejangan yang terkait dengan sisi-sisi kehidupan. Wejangan tersebut berisi ajaranajaran mengenai realitas kehidupan yang sebaiknya disadari oleh manusia. Rasa senang dan susah tidak ada yang kekal. Karena itu, manusia perlu mempunyai sisi fleksibelitas yang dalam ajaran Suryomentaram disebut dengan kemampuan mulur mangkret (Hartono, 2010).

Kawruh jiwa Suryomentaram merupakan hasil penyelidikan alam kejiwaan yang dilakukan oleh Ki Ageng Suryomentaram. Hasil penyelidikan tersebut kemudian tertuang ke dalam pemikiran-pemikiran yang sering disebut dengan kawruh jiwa. Ajaran tersebut tersebar berkat temen-temen Ki Ageng Suryomentaram 
yang sering diajak berdiskusi yang menyebarkannya kepada orang lain maupun lewet penerbitan buku atas pemikiran-pemikiran tersebut.

Suryomentaram mengungkapkan bahwa kawruh jiwa merupakan pengetahuan tentang jiwa. Manusia terdiri dari jiwa dan raga. Jiwa merupakan bagian dari manusia yang tidak terlihat, sementara raga merupakan bagian yang bias terlihat. Meskipun jiwa tak terlihat, tetapi keberadaanya dapat dirasakan. Orang dapat merasakan sakit, sedih, dan seterusnya.

Sarwiyono (2008) menjelaskan bahwa menurut Suryomentaram, rasa dalam jiwa manusia adalah benih ilmu pengetahuan. Rasa itulah yang mendorong seseorang bertindak. Rasa lapar mendorong seseorang untuk makan, rasa haus mendorong manusia untuk minum dan seterusnya. Mempelajari rasa adalah mempelajari tentang orang, sedangkan diri sendiri adalah orang. Jadi belajar tentang rasa, dapat dikatakan mempelajari tentang diri sendiri.

Prihartanti (2003) menjelaskan bahwa rasa merupakan struktur dasar manusia yang dijelaskan dalam dua dimensi, yaitu dimensi kelengkapan dan dimensi kesempurnaan. Dimensi kelengkapan (rasa sebagai alat) berupa kualitas fungsi rasa yang meliputi fungsi fisik, emosi, kognisi, dan intuisi. Dimensi kesempurnaan (rasa sebagai kemampuan) merupakan tingkat kualitas kesadaran manusia.

Konsep rasa bila dibandingkan dengan pandanagn Freud, maka makna rasa sejalan dengan insting dalam konsep psikonalisis Freud. Rasa dalam jiwa manusia adalah benih ilmu pengetahuan. Rasa itulah yang mendorong seseorang bertindak. Rasa lapar mendorong seseorang untuk makan dan rasa haus mendorong seseorang untuk minum. Sedang insting didefinisikan sebagai perwujudan psikologis dari suatu sumber rangsangan semiotik yang di bawa sejak lahir. Perwujudan psikologisnya disebut hasrat sedangkan rangsangan jasmaniah hasrat disebut kebutuhan. Jadi, keadaan lapar dapat digambarkan secara fsikologis sebagai keadaan kekurangan makanan pada jaringan-jaringan tubuh, sedang secara psikologis diwujudkan dalam bentuk hasrat akan makan. Hasrat itu berfungsi sebagai kebutuhan yang didorong tingkah laku. Orang yang lapar mencari makanan. Karena itulah insting dilihat sebagai faktor pendorong kepribadian. Insting tidak hanya mendorong tingkah laku, tetapi juga menentukan arah yang akan ditempuh tingkah laku (Hall \& Lindzey, 1993). ${ }^{46}$

Konsep kawruh jiwa Suryomentaram dijelaskan oleh (Fudyartanto, 2003) mengacu pada segala gerak dalam batin yang meliputi perasaan-perasaan, gagasan-gagasan, dan keinginan sehingga rasa hidup akan mendorong manusia untuk bergerak. Rasa mendorong orang berbuat apa saja.

${ }^{46}$ Ryan Sugiarto, dkk, Suryomentaram, Riwayat, dan Jalan Menuju Bahagia, hlm. 175-176. 
(Jatman, 2008) menyatakan bahwa rasa dalam kawruh jiwa lebih dari sekedar perasaan, emosi, suasana hati, atau sensasi. Manusia Jawa memaknai rasa sebagai pengecap, perasaan, karakter manusia dan pernyataan dari hati nurani. Suryomentaram membedakan rasa secara kualitatif sebagai rasa kramadangsa dan rasa manusia tanpa ciri. Rasa kramadangsa sebagai rasa yang dangkal dilekati oleh sifat egoistik. Rasa manusia tanpa ciri sebagai rasa yang mendalam merupakan kesadaran yang lebih luas. Rasa yang mendalam menghadirkan kesadaran bahwa rasa manusia sama saja, bahwa hidup adalah sekarang dan ada di sini, perubahan rasa senang dan susah selalu ada.

\section{F. Kawruh Jiwa dalam Tasawuf Qurani Jawi}

Konteks pandangan hidup Ki Ageng Suryomentaram ajining diri (prestise) adalah berdasarkan faktor prestasi usaha (kasab), bukan keturunan darah (nasab) sebagaimana dalam kultur feudalisme. Inilah hal fundamental yang menjadi ciri masyarakat demokratis, sebagaimana dalam teori mobilitas sosial yang memandang prestasi individu untuk mobilitas vertikal dengan variabel di antaranya pendidikan (ilmu) dan prestasi sosial yang lain. Dari sini tampak jelas bahwa raos sami merupakan karakter spesifik bentuk implementasi demokratisasi dan inklusivisme Kawruh Jiwa Suryomentaram. Sejalan dengan Firman Allah SWT dalam Ar-Ra'du: 11.

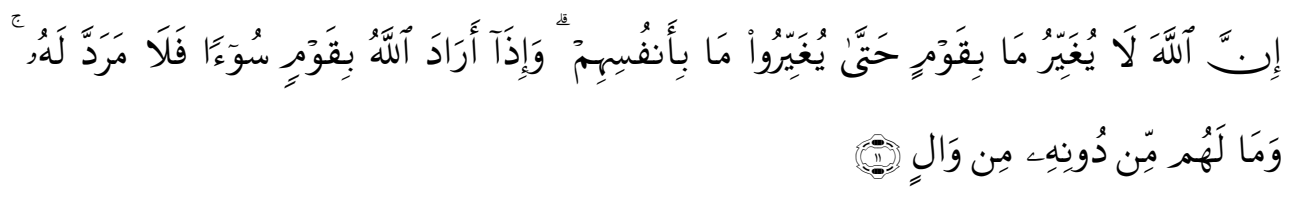

Sesungguhnya Allah tidak merubah keadaan sesuatu kaum sehingga mereka merubah keadaan yang ada pada diri mereka sendiri. Dan apabila Allah menghendaki keburukan terhadap sesuatu kaum, maka tak ada yang dapat menolaknya; dan sekali-kali tak ada pelindung bagi mereka selain Dia.

Rabi'ah binti Isma'il al-'Adawiyah, julukannya Ummu al-Khair, alBashriyah. Seorang muslimah kelahiran Bashrah Irak, yang dikenal shalihah, zahidah, dan sangat tekun dalam beribadah dan bermunajat kepada Allah SWT. Ia masyhur karena filosofi "mahabbah" atau "cinta" nya dalam beribadah. Salah satu do'a munajat "cinta” nya yang terkenal adalah sebagai berikut: Artinya: "Wahai Tuhanku, jikalau aku beribadah kepada-Mu karena takut neraka-Mu, maka jerumuskanlah aku ke dalamnya, dan jikalau aku beribadah kepada-Mu karena mengharap syurga-Mu, maka halangilah aku darinya, akan tetapi jikalau 
aku beribadah kepada-Mu karena cinta dan mengharap ridha-Mu, maka jangan Kau halangi aku untuk melihat Wajah-Mu).47

Sayid Quthb dalam Tafsir Fî Zhilâlil Qur'an menyebutkan Allah selalu mengikuti mereka dengan memerintahkan malaikat-malaikat penjaga untuk mengawasi apa saja yang dilakukan manusia untuk mengubah diri dan keadaan mereka, yang nantinya Allah akan mengubah kondisi mereka itu. Sebab Allah tidak akan mengubah nikmat atau bencana, kemuliaan atau kerendahan, kedudukan atau kehinaan, kecuali kalau mereka itu mau mengubah perasaan, perbuatan dan kenyataan hidup mereka. Maka Allah akan merubah keadaan diri mereka sesuai dengan perubahan yang terjadi dalam diri dan perbuatan mereka sendiri. Meskipun Allah mengetahui apa yang bakal terjadi dari mereka sebelum hal itu terwujud, tetapi apa yang terjadi atas diri mereka itu adalah sebagai akibat dari apa yang timbul dari mereka. Jadi, akibat itu datangnya belakangan waktunya sejalan dengan perubahan yang terjadi pada diri mereka. ${ }^{48}$

Perbedaannya, kalau dalam lingkungan sosio-kultural Ki Ageng Suryomentaram, kraton sebagai institusi pemberi gelar kebangsawanan berdasarkan hubungan darah (strukturalisme sosial genetik) dengan raja, maka pada konteks kontemporer hal itu beralih pada institusi pendidikan yang memberikan gelar kesarjanaan tersebut kapada yang bisa dan mau membayar. Akibatnya kesarjanaan bukan lagi prestasi yang butuh ketekunan dan perjuangan(strukturalisme sosial dinamika), tapi sudah menjadi prestise yang cukup hanya dibeli saja seperti komoditi barang dagangan (strukturalisme sosial ekonomik). Inilah yang dinamakan hidup slamuran oleh Ki Ageng Suryomentaram sebagai bentuk mental tidak sehat yang parah dalam kehidupan sosial. Hal ini sejalan dengan firman Allah SWT dalam Al-Qashâsh: 83

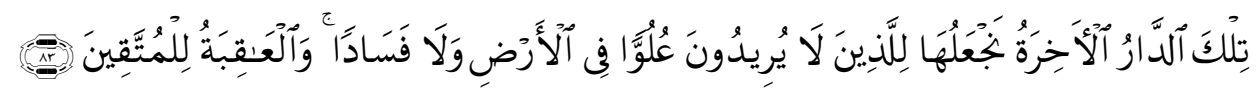

Negeri akhirat itu, Kami jadikan untuk orang-orang yang tidak ingin menyombongkan diri dan berbuat kerusakan di (muka) bumi. Dan kesudahan (yang baik) itu adalah bagi orang-orang yang bertakwa.

Dalam konteks Islam, konflik (shiqâq) dan keraguan (shakk) merupakan hal yang sebisa mungkin dihindari seseorang karena dapat menghilangkan sa'âdah (kebahagiaan), sakînah (ketenangan) dan tuma'nînah (ketentraman) sebagai syarat kebahagian dalam hidup dan memperkuat kepribadian. Shiqâq (konflik) mengakibatkan keretakan integritas diri, dan shakk mengakibatkan ambiguitas

${ }^{47}$ Shalahuddin Khalil bin Abik as-Shafadi, al-Wafi bi al-wafiyat, , juz 4, hal. 435, lihat pula al-A'lam, Khairuddin az-Zarkali, juz 3, hal. 10, serta Qadhiyyah at-tasawwuf, hlm. 42. Dinukil dari https://tatahati.wordpress.com/2011/07/04/tokoh-tokoh-dalam-dunia-tasawuf/

${ }^{48}$ Sayid Quthb, Tafsir Fî Zhilâlil Qur'an, Jakarta: Gema Insani, 2000, Jilid 7, hlm. 38 
dan ambivalensi daalam berwawasan, bersikap dan bertindak. Pengalaman konflik batin (psikologis, internal) seperti itu secara fenomenologis bisa terjadi dalam kehidupan setiap individu kapan saja dan di mana saja, dan Ki Ageng Suryomentaram telah melewatinya dengan selamat dan itulah arti bahagia (beja) yang ia cari.

Sedangkan dari telah teori spiritualisasi (tasawuf Islam), secara epistemologis shakk (skeptis) merupakan pintu pembatas dari dua hal yang kontradiktif, pada satu sisi secara positif sebagai stimulus kepada yaqîn. Sedangkan yaqîn itu sendiri merupakan wujud stabilitas jiwa yang merupakan salah satu wujud tampilan kesalahan mental, dan merupakan kebutuhan kejiwaan. Ini tampak relevan dengan sabda Nabi: "tinggalkanlah apa-apa yang meragukan kamu menuju kepada yang tidak meragukan kamu”. (H.R. at-Turmuzi)

Dari segi keimanan, syakk (skeptif) potensial menjadi pintu gerbang kepada $k u f r$ yang dapat membawa kesengsaraan abadi. Dari telah tentang struktur jiwa menurut al-Gazali, shakk menggambarkan nafs lawwâmah yakni masih menjadi tarik menarik antara nilai-nilai positif dengan negatif. Keyakinan merupakan sumber kekuatan hebat bagi jiwa untuk mampu melahirkan banyak kreasi dan perubahan besar dalam sejarah peradaban manusia, meskipun terkadang keyakinan tersebut kemudian terbukti salah. Keyakinan (tatag, gambaran madeg pribadi) juga merupakan gambaran jiwa yang telah mencapai posisi mutmainnah dalam nilai-nilai positif (kebaikan) dengan terbebas dari hal-hal yang rendah. Dari uraian tersebut tampak gambaran pencapaian kualitas jiwa "mutmainnah" pada diri Ki Ageng Suryomentaram.

Dalam ungkapan Ibnu Atha'illah al-Iskandari, Ki Ageng bisa termasuk kategori Ahwâl Tajrîd karena segala keinginannya untuk lepas dari kesibukan urusan duniawi, padahal Allah telah memberikan kedudukan di tempat yang baik. $^{49}$

\section{G. Metodologi Kawruh Jiwa dalam Tasawuf Qurani Jawi}

Menurut Ki Ageng Suryomentaram, struktur fundamental (esensi) jiwa terdiri dari dua unsur dasar yaitu raos utawi kraos gesang (rasa atau merasa hidup) dan pangertosan (pengertian).

Dalam pandangannya, Ki Ageng Suryomentaram menyatakan bahwa semua aktivitas manusia dalam kehidupannya berujung pada keberasalan dan kebertujuan untuk bisa memenuhi dua hal yang esensial-fundamental tersebut. Ketika dikaitkan, bahwa teori raos utawi kraos gesang dan pangertosan lebih

${ }^{49}$ Abdullah Asy-Syarkawi, Asyarh Al-Hikam Ibnu Atha'illah al-Iskandari, terj.Al-Hikam, Jakarta: Turos, 2017, hlm. 5. 
dekat pemaknaannya dengan fikr dan $z i k r^{50}$. Sebagaimana tertuang dalam al-

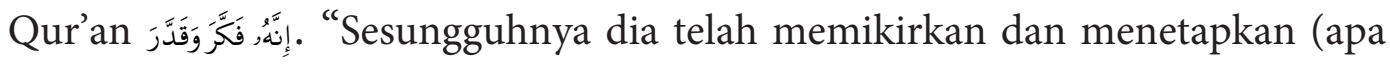
yang ditetapkannya)".

Keinginan manusia untuk mencari makna hidup bisa saja dihambat: dalam logoterapi hambatan seperti ini dinamai “frustrasi eksistensial”. Kata eksistensial dalam hal ini memiliki tiga arti, yaitu: (1) keberadaan manusia itu sendiri, atau, cara khusus manusia dalami menjalani hidupnya; (2) makna bidup; dan (3) perjuangan manusia untuk menemukaii makna yang konkrit di dalam hidupnya, dengan kata lain, keinginan seseorang untuk mencari makna hidup.

Frustrasi eksistensial bisa memicu neurosis. Logoterapi memiliki istilah khusus untuk menamam penyakit neurosis yang disebabkan oleh frustrasi eksistensial, yaitu "noögenic neuroses" (neurosis noogenik) untuk membedakannya dari neurosis yang dikena! selama ini, yaitupsychogenic neuroses (neurosis psikogenik). Neurosis noogenik tidak diakibatkan oleb dimensi kehidupan manusia yang bersifat psikologis, melainkan dimensi "noologis" (dan kata Yuimani noos, yang berarti pikiran) dalam eksistensi atau keberadaan manusia. Neurosis noogenik adalah istilah logoterapi untuk menggaris bawahi sesuatu yang secara khusus terkait dengan dimensi humanis atau manusiawi seorang manusia.

Neurosis noogenik tidak muncul akibat konflik antara dorongan dan naluri manusia, tetapi muncul karena masalah-masalah kehidupan. Salah satunya dan yang perannya cukup besar, adalab terganggunya keinginan manusia untuk mencari makna hidup.

Jelas, bahwa di dalam kasus-kasus neurosis noogcnik, metode terapi yang tepat dan memadai bukan metode psikoterapi yang umum, melainkan logoterapi; artinya, terapi yang berani menyentuh dimensi manusiawi.

Frankl menolak tegas, bahwa upaya sesorang untuk mencari makna hidup, bahkan keraguan seseorang terhadap makana hidupnya dianggap penyakit. Frustasi eksistensial bukan penyakit. Frankl memberi contoh seorang pilot tinggi AS yang mengalami itu dan awalnya didiagnosa oleh psikoanalis. ${ }^{51}$

Namun, Suryomentaram menilai esensi kawruh jiwa adalah deskripsi tentatif hakekat dan dinamika rasa setiap manusia. Ia merupakan hasil perenungan

${ }^{50}$ Sa'adi, Nilai Kesehatan Mental Islam Dalam Kebatinan Ki Ageng Suryomentaram, hlm.

${ }^{51}$ Contoh-contoh Frankl selalu mengarah kekelompok elit. Mapan secara materi, punya rasional cukup (terpelajar, ilmuwan dan seterusnya). "sekan" pancarian makna itu adalah kelompok "golongan 5" dalam khirarki Maslow. Atau karena meraka itulah yang dapat diajak diskusi menganai pencarian-makna. Bila tekanannya karena tak-bisa menyekolahkan anak, ditekan oleh orang tua, istri, suami dan seterusnya, sulit dengan logoterapi. Ini terapi kelompok "golongan ke-5" menurut Muhammad Alwi. Di nukil dari http://humanisme-kebenaran.blogspot.com/2010/03/pencarianmakna-hidup-psikologi.html\#_ftn5 
fenomenologis, pemikiran spekulatif yang terus menerus, observasi dan refleksi intuitif yang jernih, mendalam serta pengalaman hidup pribadi Suryomentaram serta lingkungan sosial yang di amati, dalam upaya mengenal jiwa manusia secara "otentik" dan komprehensif. Oleh karena itu ia menjelaskan betapa penting dan rumitnya mempelajari jiwa manusia. Diantaranya adalah:

Pertama, Djiwa punika mboten kawon penting tinimbang raga, sarehne kawontenanipun mboten kasatmata pramila langkung angle dipun sumerep. Jiwa itu tidak kalah penting dari pada raga. Karena keadaannya yang tidak tampak oleh mata, maka ia sulit untuk diamati. Esensi jiwa menurut Suryomentaram adalah raos (rasa) atau kraos (merasakan) dan pangertos (pengertian, insight), sebagaimana dijelaskan:52 Dalam Al-Mulk: 2

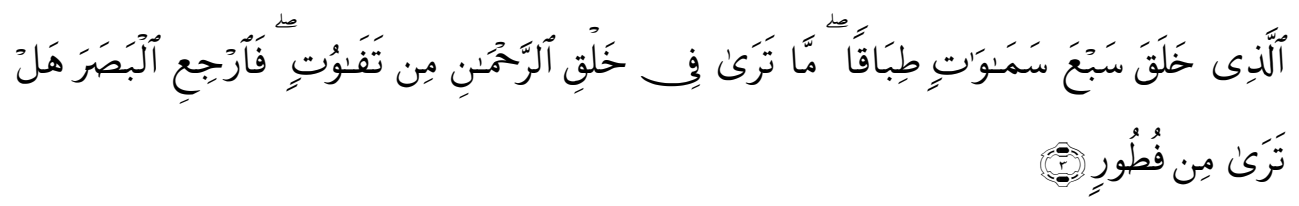

Yang telah menciptakan tujuh langit berlapis-lapis. Kamu sekali-kali tidak melihat pada ciptaan Tuhan Yang Maha Pemurah sesuatu yang tidak seimbang. Maka lihatlah berulang-ulang, adakah kamu lihat sesuatu yang tidak seimbang.

Sayid Quthb dalam tafsir Fî Zhilâlil Qur'an menegaskan langit adalah makhluk yang tetap di depan mata yang jahil yang pandangannya tidak sampai melampaui tangan yang menciptakannya dan tidak menengok kesempurnaannya. Namun ayat ini membangkitkan serta menggerakan pikiran dan renungan terhadap keindahan dan kesempurnaan ini beserta gerakan dan tujuan yang ada di balik semua itu. ${ }^{53}$

Kedua, Pirantosing manungsa punika raga (ingkang kanthi pantja indera) lan djiwa. Djiwa punika wudjudipun raos (kraos) gesang lan pangertos. Kraso gesang punika kadosta kraos aku, kraos ana, kraos bungah, kraos susah, karep lan sapanunggalanipun. Pangertospunika putusan kangge netepaken prakawis ingkang saking pabtja indera lan kraosipun. Piranti manusia itu raga dengan panca inderanya dan jiwa. Dan jiwa itu wujudnya rasa hidup dan pengertian (kognisi, intuisi). Rasa hidup itu seperti rasa aku, rasa ada, rasa senang, rasa susah, keinginan dan sebagainya. Pengertian (identik akal) adalah untuk menetapkan hal-hal yang terkait dengan panca indera dan rasa. Dengan metode filsafat, Suryomentaram mengidentifikasi esensi (hakekat) manusia dari dua sifat dasar alam benda di dunia. Dalam Yûsuf : 53.

${ }^{52}$ Suryomentaram, Ilmu Djiwa, t.k, t.p, t.t, hlm. 1. Dinukil dari buku Sa'adi, Nilai Kesehatan Mental Islam Dalam Kebatinan Kawruh Jiwa Suryomentaram, hlm. 164.

${ }^{53}$ Sayid Quthb, Tafsir Fî Zhilâlil Qur'an, Jilid 11, hlm. 350 


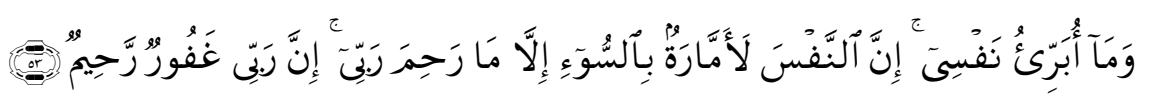

Dan aku tidak membebaskan diriku (dari kesalahan), karena sesungguhnya nafsu itu selalu menyuruh kepada kejahatan, kecuali nafsu yang diberi rahmat oleh Tuhanku. Sesungguhnya Tuhanku Maha Pengampun lagi Maha Penyanyang.

Sayid Quthb dalam tafsir Fî Zhilâlil Qur'an menyampaikan sebuah kisah yang tampak jelas unsur kemanusiaan bukan hanya unsur sastranya saja, melainkan untuk dijadikan pelajaran dan nasihat. Ungkapan-ungkapan indahnya melukiskan denyut dan debaran perasaan dengan gambaran yang indah, halus, dan lembut, dalam realitas yang utuh yang memuat semua hal yang mempengaruhinya dan semua peristiwa di dalam jiwa, di bawah bayang-bayang dan pengaruh lingkungannya. ${ }^{54}$

Setelah ditelaah dengan seksama terhadap Kawruh Jiwa Ki Ageng Suryomentaram, dengen pendekatan teori strukturalisme dapat teridentifikasi tingkatan (struktur) jiwa manusia yang hierarkis (bertingkat-tingkat), semua tingkatan jiwa tersebut dirangkum ke dalam konsep ukuran (dimensi).

Pertama, tingkatan terendah rasa (jiwa) adalah Juru Catet; Jiwa. Manungsa ukuran I yang menggambarkan fungsi kesadaran persepsi fisikal dari prilaku manusia. ${ }^{55}$ Di dalam surat Ad-Dhuha: 4

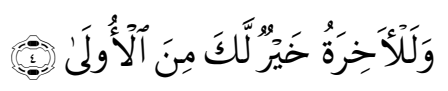

Dan sesungguhnya hari kemudian itu lebih baik bagimu daripada yang sekarang (permulaan).

Menurut teori Al-Ghazali tentang struktur nafs relatif termasuk dalam konsep nafs ammarah yang sejalan dengan konsep jiwa ukuran I Ki Ageng Suryomentaram. Nafs ammarah menggambarkan keadaan jiwa yang masih cenderung kepada orientasi dan motivasi rendah yang dikuasai kekuatan syahwat biologis dan insting semata (syahwatiyah-bahimiyah), sehingga cendrung tidak akan terpuaskan dan membentur norma etis. Namun jika dipenuhi secara legal maka nafs ammarah berubah menjadi nafs marhamah (ma rahima rabbi, nafs yang dirahmati Allah) ${ }^{56}$ Ar-Rum : 7 Allah menjelaskan bahwa:

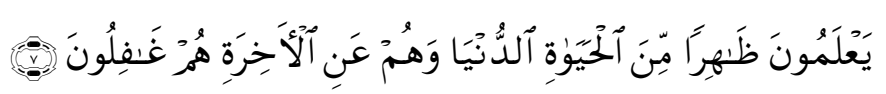

\footnotetext{
${ }^{54}$ Sayid Quthb, Tafsir Fî Zhilâlil Qur'an, Jilid 6, hlm. 357

${ }^{55}$ Sa'adi, Nilai Kesehatan Mental Islam Dalam Kebatinan Ki Ageng Suryomentaram, Jakarta: Puslitbang Lektur Keagamaan Badan Litbang Dan Diklat Kementrian Agama RI, 2010, hlm. 255.

${ }^{56}$ Sa'adi, Nilai Kesehatan Mental Islam Dalam Kebatinan Ki Ageng Suryomentaram, hlm. 
Mereka hanya mengetahui yang lahir (saja) dari kehidupan dunia; sedang mereka tentang (kehidupan) akhirat adalah lalai.

Kedua, tingkatan rasa juru cathet-cathetan yang menempatkan individu pada manungsa ukuran II (jiwa manusia tingkat II) dengan segala interest, ikatan kepentingan dan primordialismenya dalam memandang, bersikap, dan bertindak dengan sesama. Pada tingkatan ini manusia tidak tulus dalam interaksinya dengan sesama karena selalu dilandasi oleh kepentingan-kepentingan (cathetan) seperti latar belakang, pendidikan agama, profesi, madzhab, warna kulit dan sebagainya. ${ }^{57}$ AsySyan

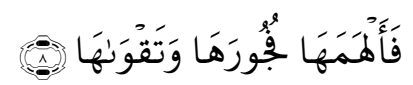

maka Allah mengilhamkan kepada jiwa itu (jalan) kefasikan dan ketakwaannya.

Ketiga, tingkatan rasa kramadhangsa, ukuran kaping III (tukang pikir, kesadaran rasional). Pada tingkatan ini, olah rasa individu sudah sampai pada tingkat yang bagus karena mengalami proses pertimbangan logis rasional. Al-Mudasir: 18

$$
\text { إِنَّهُ فَكَكَرَ وَقَدَّرَ }
$$

Sesungguhnya dia telah memikirkan dan menetapkan (apa yang ditetapkannya).

Keempat, tingkatan jiwa tertinggi adalah citra manungsa tanpa tenger (manusia tanpa ciri): ukuran kaping IV. ${ }^{58} \mathrm{Al}-\mathrm{Hasyr}: 9$

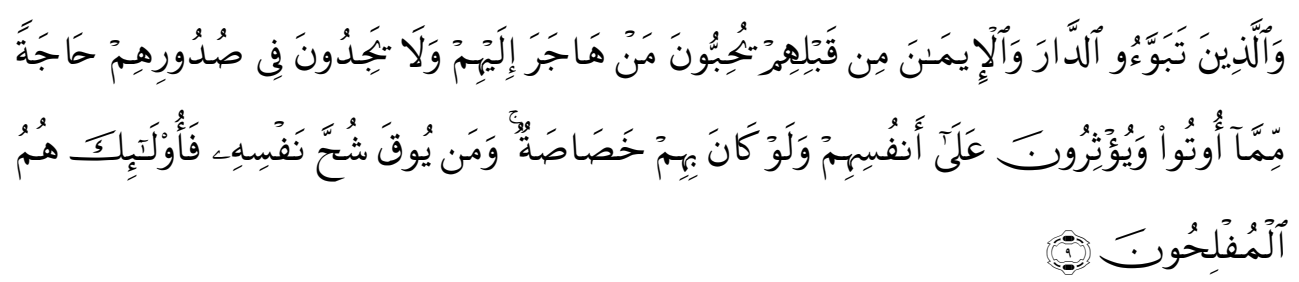

Dan orang-orang yang telah menempati kota Madinah dan telah beriman (Anshor) sebelum (kedatangan) mereka (Muhajirin), mereka (Anshor) 'mencintai' orang yang berhijrah kepada mereka (Muhajirin). Dan mereka (Anshor) tiada menaruh keinginan dalam hati mereka terhadap apa-apa yang diberikan kepada mereka (Muhajirin); dan mereka mengutamakan (orang-orang Muhajirin), atas diri mereka sendiri, sekalipun mereka dalam kesusahan. Dan siapa yang dipelihara dari kekikiran dirinya, mereka itulah orang orang yang beruntun.

Ki Ageng menjelaskannya, "Wonten gambarkramadangsa punika-Ki Ageng nudingi gambar karamadangsa-ing margi pratigan wonten aling-aling. Aling261

${ }^{57}$ Sa'adi, Nilai Kesehatan Mental Islam Dalam Kebatinan Ki Ageng Suryomentaram, hlm.

${ }^{58}$ Sa'adi, Nilai Kesehatan Mental Islam Dalam Kebatinan Ki Ageng Suryomentaram, hlm. 267 
aling punika ngalang-alangi awakipun piyambak anjok dhateng ukuran kaping sekawan. Aling-aling punika mbela dhiri ingkang wujudipun pamanggih leres. Dados aling-aling ingkang ngalang-alangi awakipun piyambak anjok dhateng ukuran kaping sekawan wujud pamanggih leres." (pada bagan kramadangsa iniKi Ageng menunjuk bagan-di jalan simpang tiga terdapat sebuah hijab. Hijab inilah yang menutupi diri kita untuk bisa sampai pada ukuran keempat. Hijab ini adalah upaya membela diri yang berwujud pendapat yang kita anggap benar. Jadi hijab yang menghalangi diri kita untuk bisa sampai pada level kesadaran keempat itu berwujud pendapat yang kita anggap benar). ${ }^{59}$

\section{H. Membangun Jiwa dalam Tasawuf Qurani Jawi}

Ki Ageng Suryomantaram menyampaikan bahwa "Sapa wonge golek kepenak liyane ngepenakke tanggane, iku padha karo gawe dhadhung sing kanggo njiret gulune dhewe", yaitu Orang yang mencari kenyamanan tanpa memberikan kenyamanan kepada orang-orang disekitarnya sama halnya dengan mengalungkan tali gantungan untuk menjerat lehernya sendiri.

Disinilah Ki Ageng menyampaikan untaian-untaian kata yang tercantum di dalam al-Qur'an yang terdapat dalam ayat-ayat al-Qur'an, yaitu dalam Surah Ali Imrân, Surah Kâf dan Surah Al-Lahab.

1. Ali-Imrân 103 (

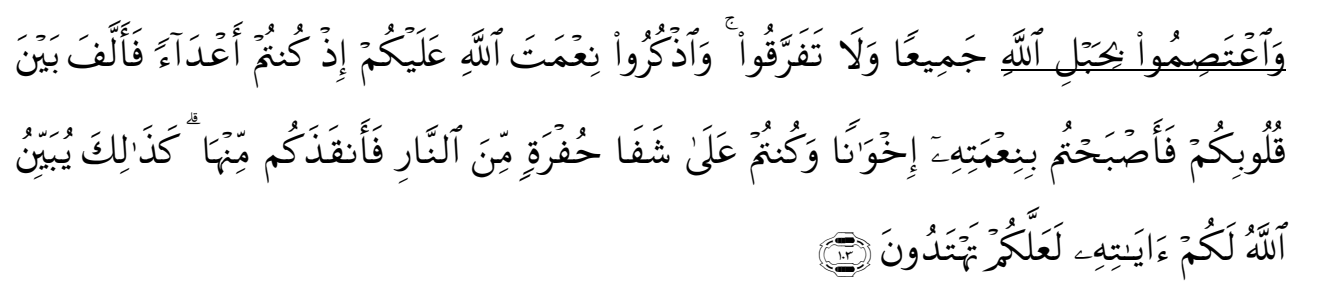

Dan berpeganglah kamu semuanya kepada tali (agama) Allah, dan janganlah kamu bercerai berai, dan ingatlah akan nikmat Allah kepadamu ketika kamu dahulu (masa Jahiliyah) bermusuh-musuhan, maka Allah mempersatukan hatimu, lalu menjadilah kamu karena nikmat Allah, orang-orang yang bersaudara; dan kamu telah berada di tepi jurang neraka, lalu Allah menyelamatkan kamu dari padanya. Demikianlah Allah menerangkan ayat-ayat-Nya kepadamu, agar kamu mendapat petunjuk.

${ }^{59}$ Muhaji Fikriono, Kawruh Jiwa Warisan Spiritual Ki Ageng Suryomentaram, Banten: Javanica, 2018, hlm. 318 
Ki Ageng Soryomentaram menuturkan dalam menyebarkan kebenaran, lebih dahulu harus menghindari perselisihan. Dan hal ini senada dengan hadist Nabi Muhammad, dari Abu Umamah RA, ia menuturkan bahwa Nabi Muhammad bersabda "Aku akan menjamin sebuah rumah di tepi surga bagi mereka yang menjauhkan diri dari perdebatan meskipun ia berada di pihak yang benar." 60

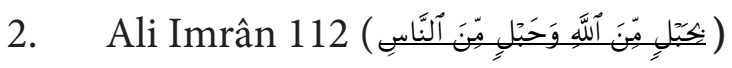

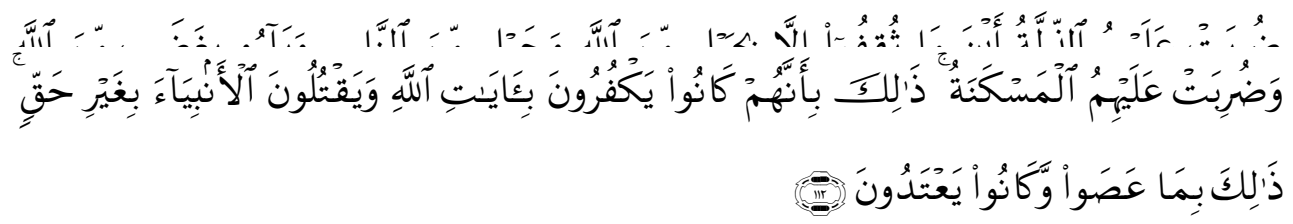

Mereka diliputi kehinaan di mana saja mereka berada, kecuali jika mereka berpegang kepada tali (agama) Allah dan tali (perjanjian) dengan manusia, dan mereka kembali mendapat kemurkaan dari Allah dan mereka diliputi kerendahan. Yang demikian itu karena mereka kafir kepada ayat-ayat Allah dan membunuh para nabi tanpa alasan yang benar. Yang demikian itu disebabkan mereka durhaka dan melampaui batas.

Menurut Ki Ageng Suryomentaram bahwa hablumminallâh adalah penerimaan. Bahwa Tuhan itu sudah memberikan kepada manusia semuanya, ketika manusia akan dititipkan baik jiwa, ruh dan sebagainya. Namun, Bagaimana kita sebagai manusia, mengelaborasi diri untuk diri pribadi karena Tuhan sudah melimpahkan semuanya. Bekitu pula dengan hablumminannâs, yakni setiap manusia itu adalah cerminan dirinya sendiri. Ketika perbuatan seseorang baik ataupun jahat maka perbuatan tersebut pun bisa terjadi pada diri manusia itu sendiri.

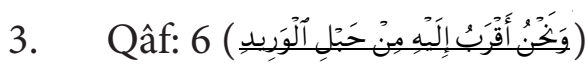

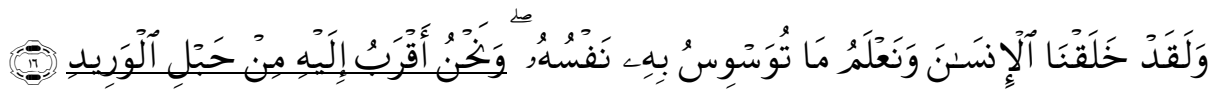

Dan sesungguhnya Kami telah menciptakan manusia dan mengetahui apa yang dibisikkan oleh hatinya, dan Kami lebih dekat kepadanya daripada urat lehernya.

Menurut Ki Ageng Suryomentaram bahwa Ibadah yg benar adalah orang yg ti-

${ }^{60}$ Mahran Mahir Utsman, Serba Tiga dari Nabi Muhammad saw, Tangerang: Lentera Hati, 2012, hlm. 203. 
dak lagi mencari tuhan diluar dirinya, karena Tuhan sudah ada dalam dirinya sedekat urat leher.

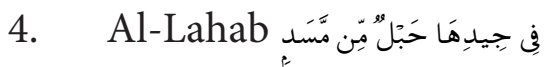

Yang di lehernya ada tali dari sabut.

Ayat tersebut mengandung dua makna. Pertama, Membawa tali dari sabut, artinya karena bakhilnya, dicarinya kayu api sendiri ke hutan, dililitkannya kepada lehernya, dengan tali daripada sabut pelepah kurma, sehingga berkesan kalau dia bawanya berjalan. Kedua, membawa kayu api kemanamana, atau membawa kayu bakar. Membakar perasaan kebencian kepada Rasulullah dengan mengada-adakan yang tidak ada. Tali dari sabut pengikat kayu api fitnah, artinya bisa menjerat lehernya sendiri.

\section{Kesimpulan}

Dari banyaknya para sufi yang terjun dalam dunia spiritual yang senantiasa berpedoman pada al-Qur'an dan Hadist, Ki Ageng Suryomentaram termasuk sederet yang dikategorikan seorang sufi tulen yang berpedoman pada tuntunan al-Qur'an dan Hadist. Hal ini disinyalir dengan setaranya ajaran-ajaran Ki Ageng Suryomentaram, misalnya pertama mulur mangkret seperti itu masih jauh dari maqâm zuhd sebagai titian awal agar hati dekat dengan al-Khâliq. Kedua keluar dalam lingkaran istana demi menemukan 'orang' seperti itu merupakan masuk maqâm taubat. Kemudian ketiga beliau menemukan maqâm mujahadah dengan melakukan pengembaraan hidup demi mencapai kebahagiaan yang sesungguhnya. Selanjutnya keempat, Ki Ageng menemukan maqâm syukur dengan menjalankan hidup sesuai dengan kebahagiaan yang sebenarnya diinginkan. Kelima, maqâm istiqâmah yang dijalankan untuk meninggalkan gemerlapnya kehidupan dunia di dalam sebuah kerajaan yang mempunyai fasilitas yang lengkap. Keenam, dengan maqâm dengki beliau melewati semua rintangan hidupnya untuk terus bisa menjaga perasaan diri dan menjauhkan sifat-sifat iri dan sombong. Ketujuh, maqâm ikhlas pun dijalankan Ki Ageng dengan rela menjalankan hidup jauh dari kemewahan dan menjalankan kehidupan dengan hati tulus. Dan sepertinya tingkatan-tingkatan (maqâmat) para penempuh jalan suci dilewatkan oleh Ki Ageng Suryomentaram. Oleh karenanya beliau pantas dikategorekan seorang sufi sunni karena menjalankan semuanya tidak keluar dari zona Al-Qur'an dan Hadist. 


\section{Daftar Pustaka}

Abdullah Asy-Syarkawi, Asyarh Al-Hikam Ibnu Atha'illah al-Iskandari, terj.Al-Hikam, Jakarta: Turos, 2017

Bagir, Haidar, Buku Saku Filsafat Islam, Bandung: Mizan, 2005

Bastaman, HD. Bastaman, Integrasi Psikologi dengan Islam, Menuju Psikologi Islami, Yogyakarta: Pustaka Pelajar, 1995, hlm. 196. Dinukil dari JURNAL KOMUNIKA, Vol. 9, No. 1, Januari - Juni 2015 Muskinul Fuad: Muskinul Fuad Psikologi Kebahagiaan Manusia.

El-Ashiy, Abdurrahman El-Ashiy, Makrifat Jawa untuk Semua, Jakarta: Serambi Ilmu Semesta, 2011, Cet. I

Fikriono, Muhaji, Puncak Makrifat Jawa Pengembaraan Batin Ki Ageng Suryomentaram, Jakarta: Penerbit Noura Books (PT Mizan Publika), 2012

Kartanegara, Mulyadi, Lentera Kehidupan Panduan Memahami Tuhan, Alam, dan Manusia, Bandung: Mizan, 2017, Cet. I

Mahir Utsman, Mahran Mahir Utsman, Serba Tiga dari Nabi Muhammad saw, Tangerang: Lentera Hati, 2012

Muthahhari, Murtadha, Fitrah: Menyingkap Hakikat, Potensi, dan Jatidiri Manusia, Jakarta: Penerbit Lentera, 2008, hlm. 31. Dinukil dari JURNAL KOMUNIKA, Vol. 9, No. 1, Januari - Juni 2015 Muskinul Fuad: Muskinul Fuad Psikologi Kebahagiaan Manusia

Nitinegoro, R.M. Soemardjo Nitinegoro, Sejarah Berdirinya Kota Kebudayaaan Ngayogyakarta Hadiningrat, Yogyakarta: Foundation of Higher Education PUTRAJAYA, 1980

Quthb, Sayid, Tafsir Fî Zhilâlil Qur'an, Jakarta: Gema Insani, 2000, Jilid 7

Rakhmat, Jalaluddin Rakhmat, Meraih Kebahagiaan, Bandung: Simbiosa Rekatama Media, 2008, hlm. 107, Lihat juga tulisan Jalaluddin Rakhmat, Tafsir Kebahagiaan, Bandung: Serambi, 2010. Dinukil dari JURNAL KOMUNIKA, Vol. 9, No. 1, Januari - Juni 2015 Muskinul Fuad: Muskinul Fuad Psikologi Kebahagiaan Manusia.

Sa'adi, Nilai Kesehatan Mental Islam Dalam Kebatinan Kawruh Jiwa Suryomentaram, Jakarta: Puslitbang Lektur Keagamaan Badan Litbang dan Diklat Kementerian Agama RI, 2010

Sarwiyono, Ratih Sarwiyono, Ki Ageng Suryomentaram Sang Plato Dari Jawa, Yogyakarta: Cemerlang Publishing, 2017.

Sentanu, Erbe Sentanu, Quantum Ikhlas: Teknologi Aktivasi Kekuatan Hati, Jakarta: Elex Media Komputindo, 2008, hlm. 19. Dinukil dari JURNAL KOMUNIKA, Vol. 9, No. 1, Januari - Juni 2015 Muskinul Fuad: Muskinul Fuad Psikologi Kebahagiaan Manusia

Suryomentaram, Grangsang, Kawruh Begja Wejanganipun Ki Ageng Suryomentaram, Buku I, Jakarta : CV. Haji Masagung, 1989

Suryomentaram, Grangsang, Kawruh Begja Wejanganipun Ki Ageng Suryomentaram, Jilid II, Jakarta : CV. Haji Masagung, 1990

Yuswohady, "Meredefinisi Ukuran Sukses”, dalam Kompas, Jum'at, 12 Desember 2014. Dinukil dari JURNAL KOMUNIKA, Vol. 9, No. 1, Januari - Juni 2015 Muskinul Fuad: Muskinul Fuad Psikologi Kebahagiaan Manusia.

218 Mumtäz Vol. 2 No. 2, Tahun 2018 